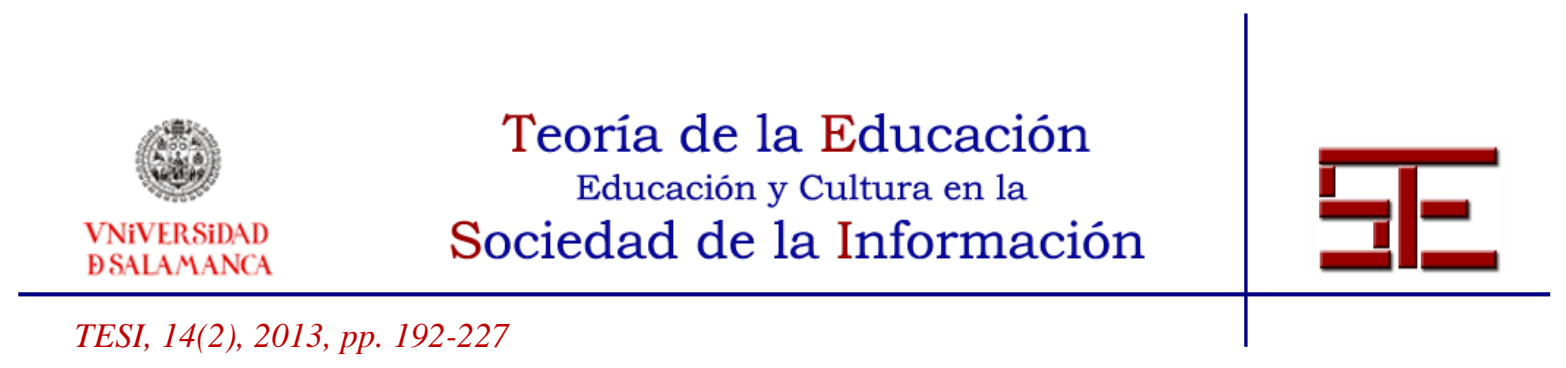

\title{
UN MUSEO PEDAGÓGICO EN INTERNET: DISEÑO, DESARROLLO Y EVALUACIÓN
}

Resumen: Las webs de los Museos Pedagógicos constituyen una ventana abierta a la ciudadanía general y a los especialistas del campo de la historia y de la educación. Es necesario que éstas ofrezcan un producto en línea que capte la atención y el interés del visitante. En este artículo sintetizamos un estudio de caso en el que analizamos el diseño e implementación de la web de uno de los Museos Pedagógicos a nivel nacional más cercanos al público, el Museo de la Escuela Rural de Asturias. Nos planteamos comprobar su potencial para atraer y servir como recurso didáctico a un público diana: los estudiantes de Magisterio. Para ello se ha elaborado un estudio evaluativo de la web cuyo propósito es sondear la opinión del alumnado. A la vista de los resultados obtenidos podemos considerar que la web del Museo podría constituir un espacio idóneo y complementario para la formación del profesorado.

Palabras clave: Museo virtual; museografía didáctica; estudio de caso; formación del profesorado.

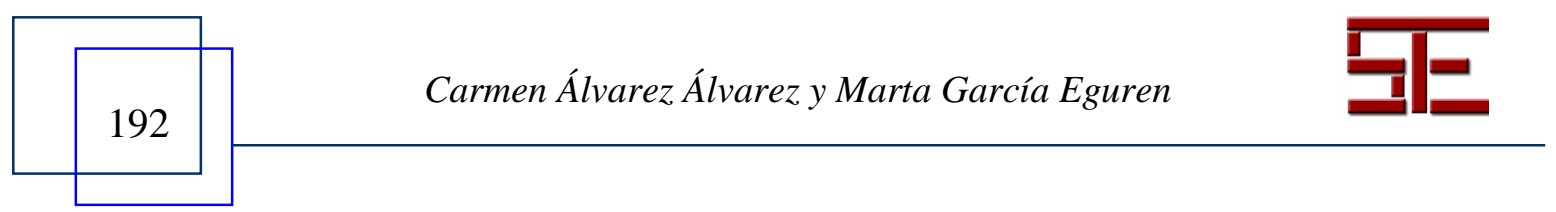




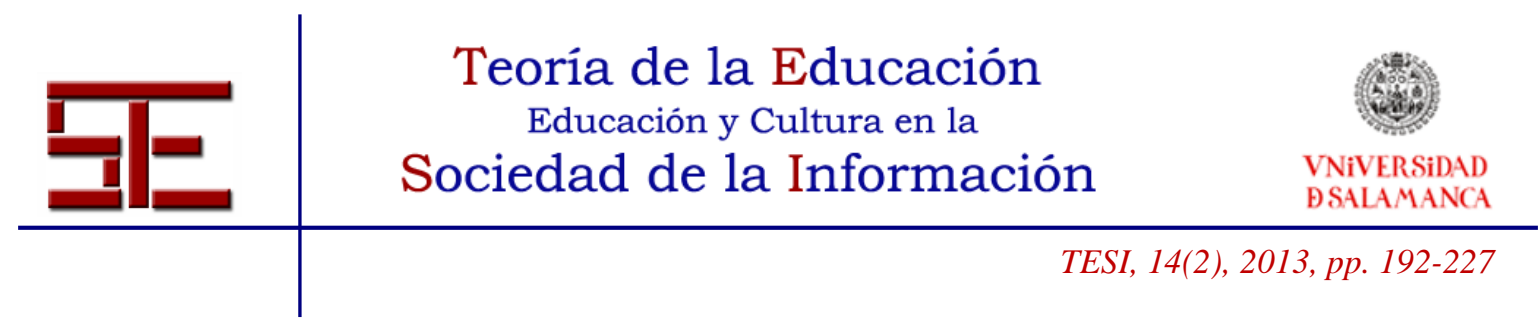

\title{
AN ONLINE PEDAGOGICAL MUSEUM: DESIGN, DEVELOPMENT AND EVALUATION
}

\begin{abstract}
The websites of the Pedagogical Museums are a window open to the general public and specialists in the field of history and education. It is necessary that they offer a product online that capture the attention and interest of the visitor. In this article, we synthesized a case study in which we analyze the design and implementation of the web of one the Pedagogical Museums closer to the public at the national level, the Museum of Rural School of Asturias. We set to see its potential to attract and serve as a resource to a target audience: students in teacher training. This has been developed an evaluative study of the web whose purpose is to poll the opinion of students. In the light of the results obtained, we can consider that the website of the Museum could be an ideal and complementary space for teacher training.
\end{abstract}

Keywords: Virtual museum; didactic museography; case study; teacher training.

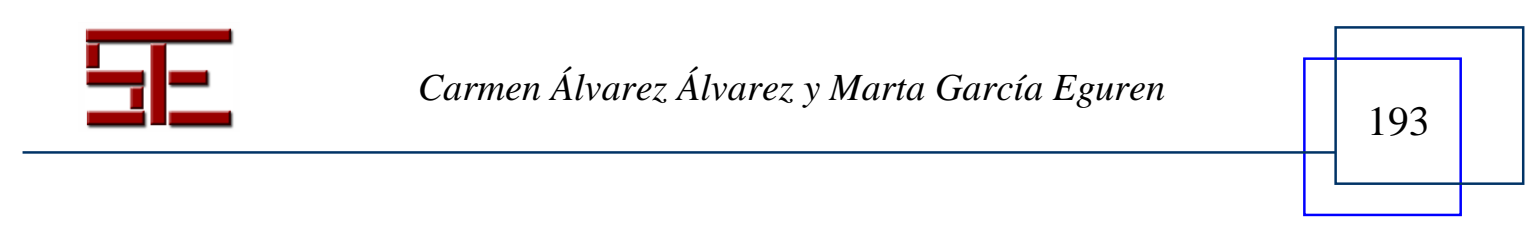




\begin{tabular}{cc} 
Teoria de la Educación \\
Educación y Cultura en la \\
$\begin{array}{c}\text { VNiVERSDAD } \\
\text { BSALAMANCA }\end{array}$ & Sociedad de la Información \\
\hline TESI, 14(2), 2013, pp. 192-227 & \\
\hline
\end{tabular}

\section{UN MUSEO PEDAGÓgICO EN INTERNET: DISEÑO, DESARROLLO Y EVALUACIÓN}

Fecha de recepción: 22/01/2013; fecha de aceptación: 01/06/2013; fecha de publicación: 30/07/2013

Carmen Álvarez Álvarez

alvarezmc@unican.es

Universidad de Cantabria

Marta García Eguren

meguren5@yahoo.es

Red de Museos Etnográficos del Principado de Asturias

\section{LOS MUSEOS PEDAGÓGICOS EN INTERNET}

En la actualidad toda institución educativa y cultural tiene entidad real y en red. Algo que hace unos años parecía impensable es hoy, sin embargo, un reto a afrontar para la mayor parte de los proyectos educativos y culturales del mundo: estar accesibles a toda la ciudadanía. En este panorama, los museos no son una excepción (Soren, 2005; Huerta, 2011; Vicente, Camarero y Garrido, 2012).

Actualmente, los museos se encuentran en una etapa en la que deben aceptar nuevos desafíos y buscar nuevos canales para hacer llegar su mensaje a un público cada vez más heterogéneo. Han de encontrar los medios para entablar nuevas relaciones con un público que aspira a dejar de ser un mero espectador, para favorecer que el visitante pueda personalizar su experiencia y todo ello requiere implantar un nuevo modelo de difusión, abierto y multidireccional, que se hace posible a través de las páginas web. Fontal (2006, 194) señala que superar las barreras físicas y acceder a todos los lugares del mundo a los que existe Internet permite multiplicar las funciones de difusión y continuar la idea del museo fuera del museo, "el museo que sale y no solo el que recibe o deja entrar", permite además al museo tener un canal abierto de comunicación con todos los lugares del mundo a través de las redes sociales. La proyección externa del museo se ve favorecida por la existencia de Internet y permite que se acceda desde muchos más lugares a la colección de los museos, así como a algunas de sus acciones educativas.

En los últimos años la irrupción de las tecnologías de la información y la comunicación llevan aparejado un cambio al que el mundo de los museos no debe renunciar, sino adaptar su proyecto museológico a los nuevos planteamientos que posibilita la tecnología. Las

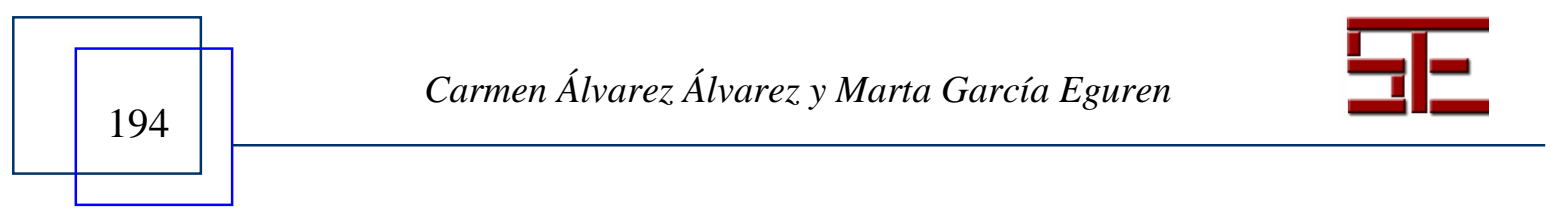




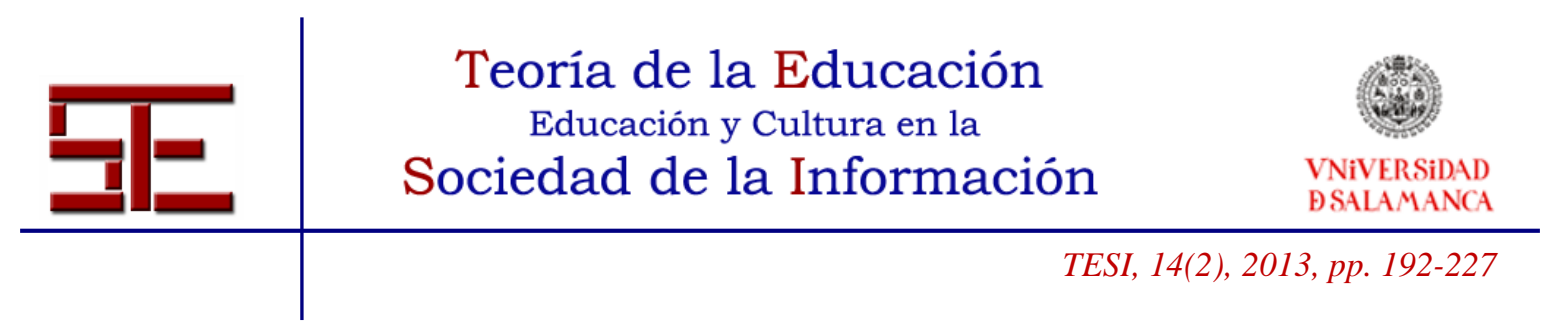

Pinacotecas, Museos Etnográficos, Museos de Arqueología, etc., más relevantes han abierto sus puertas a través de la web para todos los públicos, generando espacios de especialistas de diferente tipo, interacción y aprendizaje de sumo interés para investigadores, académicos, científicos, teniendo muy presente a todo tipo de públicos e incorporando diferentes niveles de lectura para llegar a un amplio horizonte destinatario, estableciendo itinerarios para crear un museo a la carta, que se adecúe lo más posible a las necesidades y expectativas de cada usuario (Mateos, 2008).

En este marco, los Museos Pedagógicos, es decir, aquellos que se dedican al estudio, conservación, exposición y difusión del patrimonio cultural escolar, no son una excepción. De hecho, sus páginas web deberían ser una especie de cofre donde se vuelque toda la información procedente de la investigación realizada, reflejando las distintas fuentes que conducen a la obtención de los contenidos, donde adquieren el máximo protagonismo los informantes que nos descifraron las claves de la vida en las aulas en las diferentes etapas. La página web garantiza la seguridad de su conservación y difusión (Santacana y Lloch, 2009; García Eguren, 2006).

Los Museos Pedagógicos en red poseen un enorme potencial para la investigación didáctica e histórica en educación y son una fuente imprescindible en la formación inicial y permanente del profesorado (Calaf, 2009; García Eguren, 2010) ya que este tipo de público especializado requiere información elaborada y específica, pero sobre todo necesita llegar a saber cuáles son las vías utilizadas para la obtención de la información, es decir, cómo se ha efectuado la investigación (Santacana y Martín Pinol, 2010). Esta es sin duda una de las condiciones que debe cumplir la web de un Museo Pedagógico.

Sin embargo en España, como en la mayoría de países europeos, a excepción de la corriente sajona, encontramos las páginas web de estas instituciones en fase incipiente, mientras otras inician una etapa de "madurez" de tal manera que en la mayoría de los casos se limitan a ser un mero tablón de anuncios, comunicando exclusivamente los espacios que los componen y las diferentes actividades programadas. Por lo general, las webs de los Museos Pedagógicos están configuradas en torno a informaciones administrativas (localización del museo, órganos de gobierno, referencias para establecer el contacto, horarios de apertura, precio de la entrada), posibilidades de visita (individual, pequeños grupos, grupos numerosos), servicios que se ofrecen (préstamos de locales, préstamo de materiales, audio-guías, etc.). Pero, ¿estas webs realmente sirven al objetivo de acercar la escuela del pasado al visitante? ¿Estas webs son útiles para el profesorado

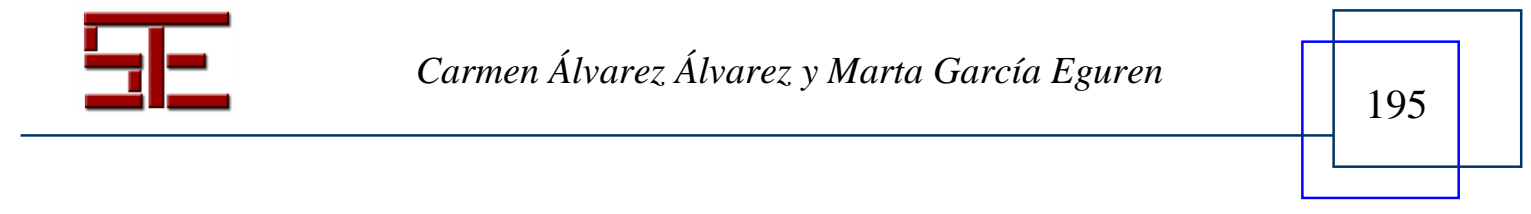




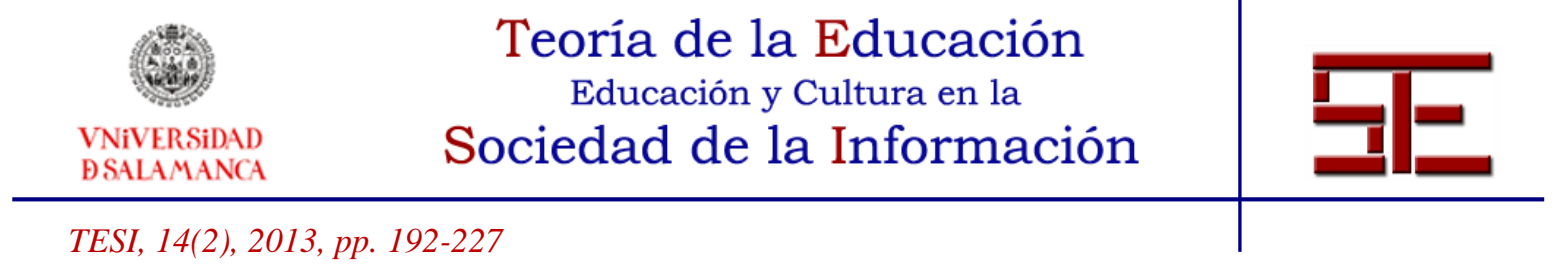

que tiene interés en acercar la historia de la escuela a sus estudiantes? ¿Estas webs son interesantes para el historiador o didacta que se dedica a la investigación?

La página web de un museo debe contener información, debe actualizarse frecuentemente, debe ofrecer diferentes niveles de lectura, debe ser accesible al gran público sin perder fidelidad ni rigor y en ella deben encontrar estímulo para explorar en mayor profundidad los especialistas, así como encontrar una vertiente científica, pero más lúdica otro tipo de visitantes (Mateos, 2012). No debemos olvidar que la investigación sobre los Museos Pedagógicos en la red debe contribuir a la creación y recreación de recursos útiles para los usuarios, con especial hincapié en el profesorado, en formación y en ejercicio, en cualquier nivel educativo.

Hoy día contamos con los estudios de Mateos (2012) sobre la comunicación en los museos y algunos otros, también incipientes, como los de Rivero (2009) y Álvarez (2010, 2012), dirigidos a explorar buenas prácticas didácticas en museología on-line. Conocer estas buenas prácticas, efectivamente, es imprescindible, por eso, en este artículo, entre otras cosas, exploramos una: la web de un Museo Pedagógico realizada con especial cuidado.

Como ha planteado Álvarez (2010), una buena web de un Museo Pedagógico tiene que proporcionar diferentes niveles de lectura: como espacio de pensamiento y reflexión, como espacio de producción cultural, como espacio educativo de relaciones humanas, como agente de comunicación y socialización, como forma de saber y vehículo para la construcción de la propia identidad, como mediador pedagógico, como entorno para el aprendizaje y como recurso para la atención de la diversidad.

El estado de la investigación en el campo de las páginas web en museos pedagógicos es muy incipiente y aún queda un duro trabajo por delante para adaptar todas las posibilidades que la tecnología ofrece, muchas de las cuales quizá no alcanzamos ni a imaginar en estos momentos. Todavía hoy la museografía didáctica en materia de museos pedagógicos se encuentra en una fase primaria en el terreno presencial, y esto en cierto modo explica que su transposición a la Red se encuentre en una fase embrionaria. Sirva como ejemplo el Museo Pedagógico y del Niño de Albacete, que está atravesando el peor momento de su ya larga historia. El museo se halla a la espera de la construcción de una nueva sede y, sin embargo, ofrece una de las mejores páginas web de museos pedagógicos en nuestro país, que incluye mayor nivel de interactividad y de contenidos (www.museodelnino.es).

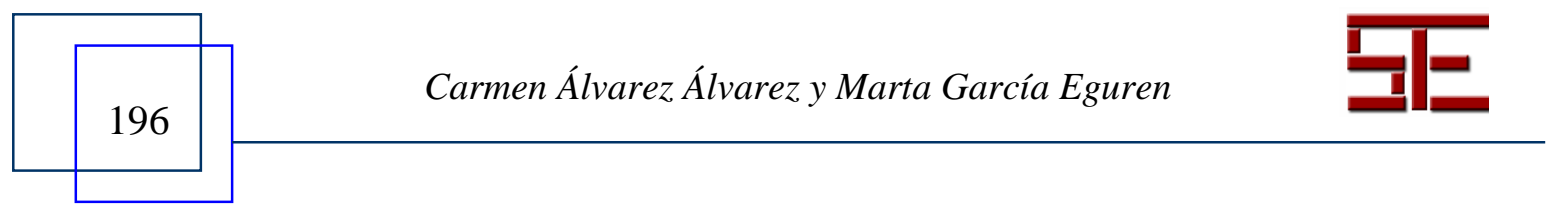




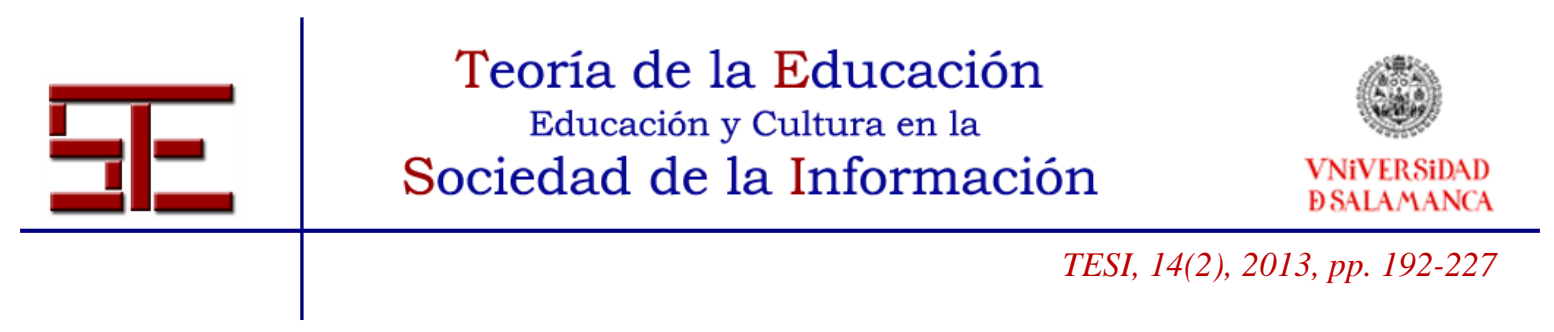

Explorar las posibilidades y las rápidas transformaciones que nos facilita la Red puede dotar a la imprescindible educación museística de la flexibilidad de la que en muchas ocasiones ha carecido para acomodarse a los nuevos contextos culturales, favoreciendo la multiplicidad de estímulos y la comunicación de la información en un formato más próximo a nuestros códigos de comprensión, atendiendo a la demanda de la sociedad actual (Calaf y Fontal, 2006).

Dentro de las múltiples potencialidades didácticas, las páginas web son capaces de permitir una serie de enlaces que lleven a otras páginas vinculadas con contenido patrimonial, histórico, educativo, didáctico, que otorgan al visitante una excelente oportunidad para seguir profundizando por medio de la curiosidad y de este modo cuando llegan al museo ya se ha abierto un diálogo entre el visitante virtual y el patrimonio, que le conduce a contemplar el museo como un lugar de disfrute y reflexión en el que se producirá la construcción del conocimiento de manera amena (Calaf, 2009).

Todo lo comentado anteriormente nos hace pensar que la página web de un Museo Pedagógico, al igual que la museografía del espacio real, debe apelar a los sentidos y hacer que fluya la empatía, como ha recogido Wagensberg (2001) en sus investigaciones. Este investigador ha sabido captar la esencia de la verdadera interactividad: la interacción mental. Es esencial que las webs de los Museos Pedagógicos transmitan la realidad de las distintas etapas de la Historia de la Educación y contengan información sobre cómo se ha construido el proyecto museológico, explicando cómo se ha llevado a cabo la investigación y no sólo mostrando una colección de objetos, porque los objetos son materia inerte si no se interpretan adecuadamente, acompañándolos de los relatos correspondientes (Santacana y Martín Pinol, 2010).

Los museos en la actualidad sienten la necesidad de competir para atraer la atención del público, para ello, no basta con utilizar la Red como tablón de anuncios para informar de lo que el museo ofrece en su sede física, sino que es necesario ofrecer un producto en línea que capte la atención y el interés del visitante. Si el museo, a través de su página web, es capaz de llegar a motivar al futuro visitante, se conseguirá entablar un diálogo necesario para que se produzca un aprendizaje significativo y enriquecedor puesto que a través del papel activo que adquiere el espectador se facilita la comprensión y con ella la posibilidad de que llegue a formarse un proceso de construcción personal del conocimiento histórico-educativo. El reto que tenemos que asumir lo ha planteado Escolano con precisión:

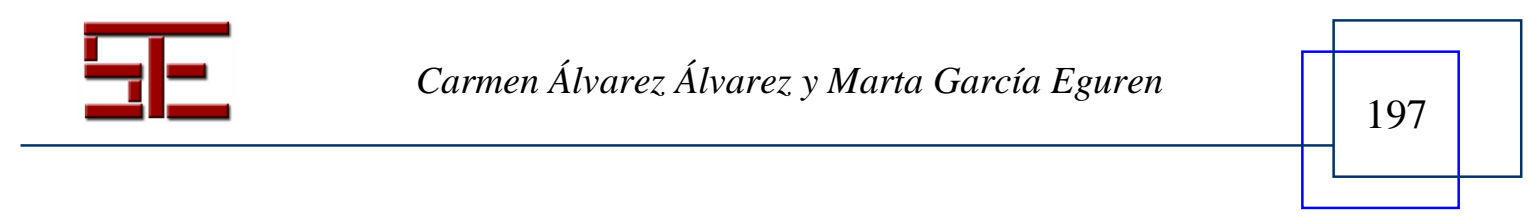




Teoria de la Educación
Educación y Cultura en la
$\begin{gathered}\text { VNiVERSIDAD } \\ \text { BSALAMANCA }\end{gathered}$

"Dialogar desde el presente, con las huellas que el pasado histórico-educativo ha objetivado en la memoria social, no es sólo un intento de revivir el sentimiento de una tradición, sino una manera de ser en el tiempo, es decir, un modo de afrontar los problemas educativos que nuestra época plantea desde la perspectiva que la historicidad suscita" (Escolano, 2007, 7).

\section{MARCO METODOLÓGICO DE INVESTIGACIÓN}

En este artículo nos proponemos ofrecer al lector los resultados de un estudio de caso realizado sobre un Museo Pedagógico relevante en el panorama nacional: el Museo de la Escuela Rural de Asturias (MERA), situado en Vinón (Cabranes, Asturias). Hemos elegido este Museo Pedagógico porque es considerado por los investigadores del campo como uno de los cuatro Museos Pedagógicos españoles que tiene detrás un proyecto museológico más auténtico y ejemplar (Calaf, 2009; Santacana y Llonch, 2009), además del Museo Pedagógico de Galicia, el Museo Pedagógico de Aragón y el Museo Pedagógico Sierra Pambley de León (García Eguren, 2010; Álvarez y García Eguren, 2011).

Este museo forma parte de la Red de Museos Etnográficos del Principado de Asturias. Fue abierto al público en el año 2005 y se ubica en la primera escuela construida en el municipio (1906). Alberga una gran colección de mobiliario, útiles y material escolar, que datan de 1911 a 1970.

La visita ofrece un recorrido cronológico por la historia de la educación en Asturias. El visitante tiene la posibilidad de adentrarse en la recreación de una escuela republicana, de una escuela franquista y de penetrar en el espacio privado destinado a vivienda del maestro y la maestra, en el cual se refleja su vida familiar y laboral. La museografía evocadora de las aulas y la vivienda tiene como objetivo incitar a los visitantes a formar parte de la escenografía e interactuar con sus elementos. Además, el testimonio de los antiguos alumnos que un día se educaron en sus aulas está presente en el museo, de forma audiovisual y también presencial, para obtener una amplia visión sobre la escuela, su arquitectura, métodos y medios didácticos y modo de vida de maestros y alumnos en el medio rural.

Si bien es cierto que los Museos locales, debido a su precariedad económica, son la "cenicienta" de los museos (Santacana y Llonch, 2009), cabe destacar que éste, pese a ser local, ha conseguido mantener un alto rigor científico en la exposición, debido, sin duda, a la autenticidad de su discurso museográfico, logrando la aceptación popular y académica por su contenido e implementación didáctica, tanto en su versión real como en la digital.

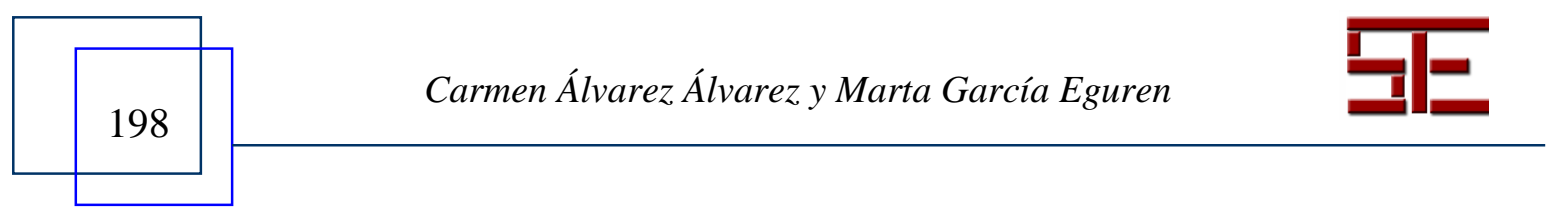




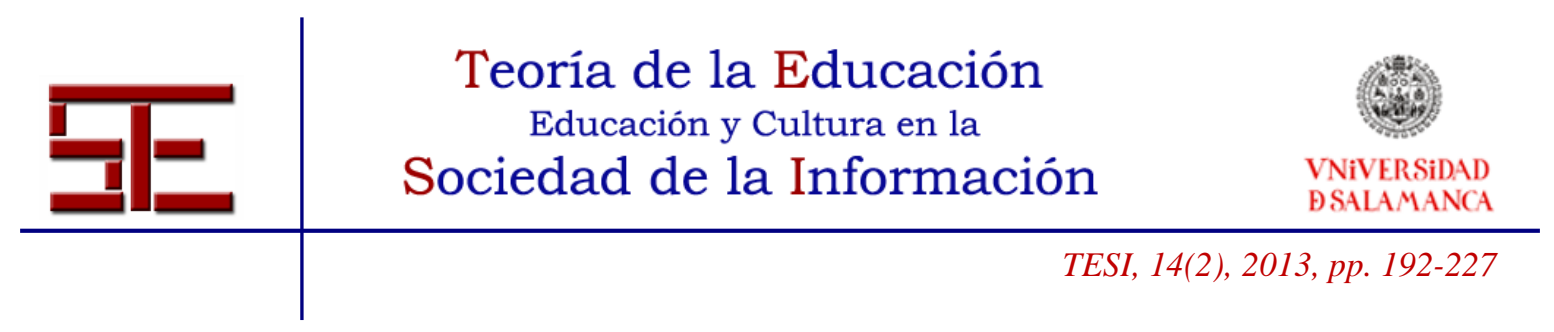

La recreación del espacio se ha hecho desde un punto de vista panorámico, transportando al espectador al interior de la escena, dándole la posibilidad de interactuar dentro de ella con libertad. La escenificación pretende mostrar el proceso evolutivo y comparativo de las diferentes etapas en la Historia de la Educación en Asturias, desde el siglo XIX hasta los años setenta del siglo XX.

Debemos reconocer el esfuerzo de su dirección para investigar y efectuar su implementación en la Red, porque se puede afirmar que, para su realización y desarrollo, se contó con una escasez de recursos, como es habitual en los museos dependientes de un ayuntamiento pequeño y con un personal limitado. En 2008 abrió sus puertas virtuales la página: www.museodelaescuelarural.cabranes.com, ofreciendo al visitante on-line recursos educativos y didácticos, que han hecho de él una referencia indispensable para la elaboración de proyectos museológicos presenciales y en red, ya que durante los años 2001 al 2008 el museo fue objeto de visitas por parte de personal vinculado a proyectos museográficos etnográficos de Asturias y también de profesionales relacionados con la elaboración de Museos Pedagógicos en otras autonomías como Cantabria, País Vasco, Cataluña y Castilla y León.

\subsection{Marco metodológico: el estudio de caso}

Para investigar sobre las webs de los Museos Pedagógicos podemos elegir entre diferentes posibilidades: en nuestro caso, hemos elegido el estudio de caso para explorar en profundidad la implementación didáctica de la web del Museo Pedagógico de la Escuela Rural de Asturias. Las razones para su selección han sido ya anteriormente recogidas, de modo que en este apartado plantearemos fundamentalmente las razones en las que se apoya la elección de este marco de investigación y su potencial científico.

El objetivo último de los estudios de caso es conocer una unidad de análisis en profundidad con el interés de ofrecer ideas que contribuyan a mejorar esa realidad local y tomar decisiones informadas (Martínez, 2007; Stake 2005; Álvarez y San Fabián 2012), que, a su vez, puede ser de utilidad para otros casos, ya sean éstos más o menos afines (Bassey, 2000; Chavarría, Hampshire y Martínez, 2004; Coller, 2005; Martínez, 2008; Grandon, 2011).

Según Stake $(2005,11)$, la nota distintiva del estudio de casos está en la comprensión de la realidad objeto de estudio: "El estudio de casos es el estudio de la particularidad y de la complejidad de un caso singular, para llegar a comprender su actividad en

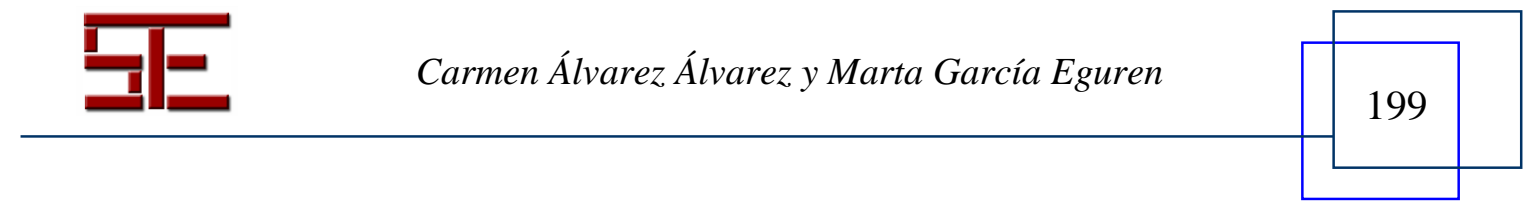




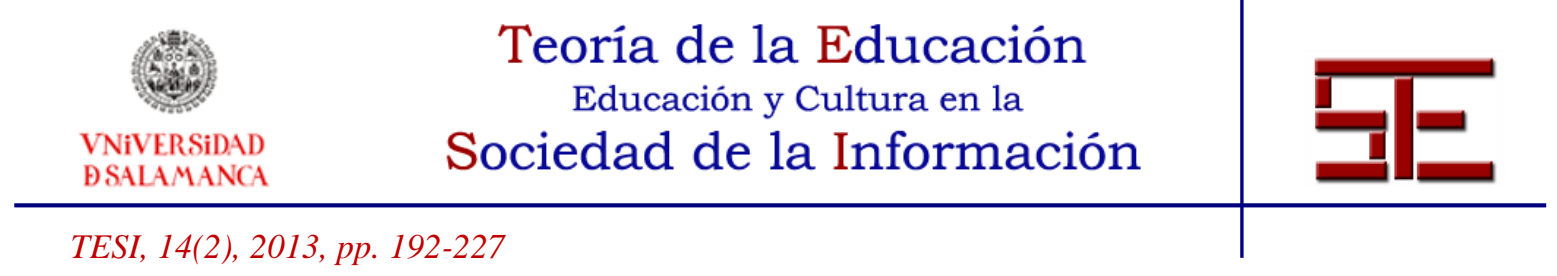

circunstancias importantes". La potencia y justificación investigadora de un estudio de caso se basa en el supuesto de que lo global se refleja en lo local, es decir, en la naturaleza holográfica de la realidad, describiendo cualquier proceso de una unidad de vida en sus diversas interrelaciones con su escenario cultural.

Investigar sobre la implementación de las webs de los Museos Pedagógicos es algo aún novedoso y difícil, en tanto a que los estudios al respecto son incipientes y los investigadores tienen poco control sobre los acontecimientos, aspecto en el que los estudios de caso son particularmente válidos (Yacuzzi, 2005; Álvarez y San Fabián, 2012). Autores como Cebreiro y Fernández (2004: 667) afirman que es conveniente desarrollar un estudio de caso "cuando el objeto que se quiere indagar está difuso, es complejo, escurridizo o controvertido. Es decir, para analizar aquellos problemas o situaciones que presentan múltiples variables y que están estrechamente vinculados al contexto en el que se desarrollan". Tal es la situación que planteamos.

\subsection{Objetivos}

Los objetivos generales y específicos de esta investigación son:

1. Explorar la implementación didáctica de la web del MERA, de manera cualitativa.

1.1. Conocer el proceso de diseño de la misma.

1.2. Conocer su proceso de desarrollo e implementación didáctica.

2. Evaluar la web del museo dando a revisar la misma a un público diana: los estudiantes de Magisterio, de manera cuantitativa.

2.1. Valorar la vigencia de los recursos didácticos de la web.

2.2. Valorar el potencial de recursos alojados en la web.

3. Extraer conclusiones que permitan orientar la mejora en la implementación didáctica de la web del MERA.

\section{ESTUDIO DE CASO: EL MERA}

En este apartado se comentará el estudio de caso realizado, deteniéndonos en las tres fases más relevantes en el proceso de implementación de la web del museo: diseño, desarrollo y evaluación.

- Para abordar las dos primeras, el diseño y el desarrollo, se dará cuenta de un proceso de investigación cualitativo basado en el análisis de contenido de la página web y de entrevistas con informantes clave que tuvieron un papel protagonista en el proceso de implementación de la web.

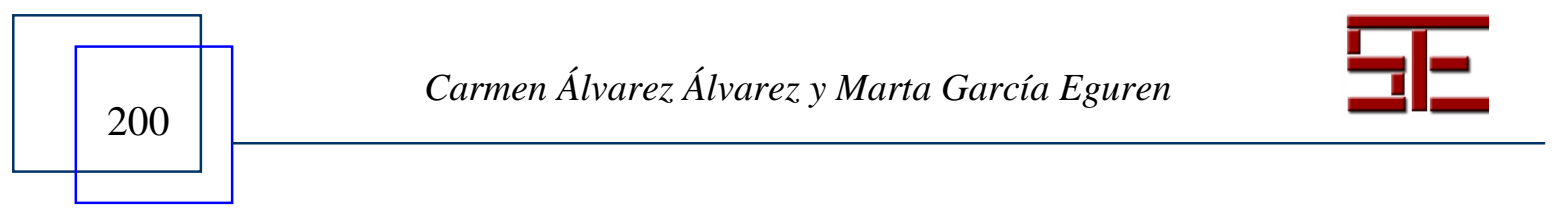




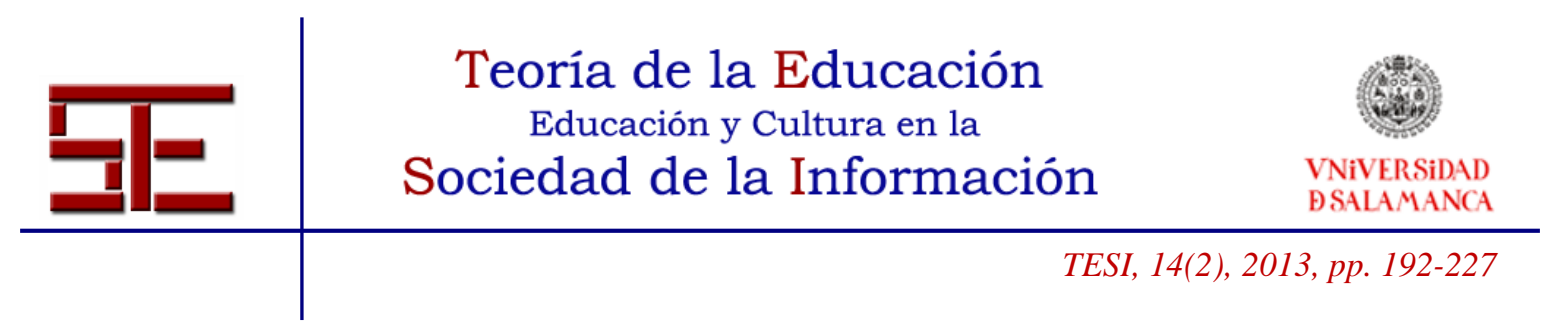

- Para abordar la tercera, la evaluación, se pasó un cuestionario a un público diana y se analizaron en profundidad los resultados.

\subsection{Diseño y desarrollo de la web}

El diseño de la página web del MERA, como hemos podido saber por el proceso de investigación, ha sido realizado con la intención de completar las visitas de los usuarios con informaciones de calidad (a través de explicaciones, visita virtual y actividades didácticas) y de abrir sus puertas digitales a aquellos que no pueden hacerlo presencialmente. El objetivo de esta web, en el futuro debería ser llegar a una fase más avanzada, creando un Museo Pedagógico Virtual.

Dadas las circunstancias presupuestarias y de infraestructuras en las que se hallaba el museo, haber tenido la posibilidad de crear una página que constituye una prolongación del mismo en la Red aportando información de calidad con diferentes niveles de lectura, asequible a todos los públicos y con información útil, tanto antes de efectuar la visita, como para ampliar conocimientos después de ésta, es un logro de mucho interés en sí mismo. Además, la web (www.museodelaescuelarural.cabranes.com) permite acercarse a la investigación sobre la que se fundamenta el museo, potenciando el descubrimiento y permitiendo al usuario crear sus propias hipótesis y sacar sus conclusiones.

Para efectuar el diseño de contenidos y favorecer que éstos discurrieran en paralelo con los del museo presencial, la directora del museo se ocupó principalmente de esta tarea y encargó el diseño gráfico a una especialista ${ }^{1}$. Para el diseño de la web ambas trabajaron en una relación horizontal, trabajando in situ, para así poder transmitir tanto conceptos como tramas, que ha dado como resultado un diseño coherente con el museo presencial. La textura es evocadora y se basa en la exaltación de la presencia de materiales como el papel antiguo, las fotografías de la época, los periódicos, libros y cuadernos, los tejidos y bordados, maderas, cuero, etc. Existe una equiparación formal de los objetos y el mobiliario que predominan en el museo presencial, ya sean libros, cartas, pizarras, documentos antiguos, cuadros, fotografías, etc. Así mismo se ha querido asociar el

\footnotetext{
${ }^{1}$ Noelia Estarelles Nájera. Licenciada en Bellas Artes por la Universidad del País Vasco y actualmente trabaja como profesora del Departamento de Didáctica de la Expresión Musical, Plástica y Corporal de la Universidad de Valladolid, siendo seleccionada por el grupo MIRAR de la Universidad de Oviedo para la realización de la citada página web.
}

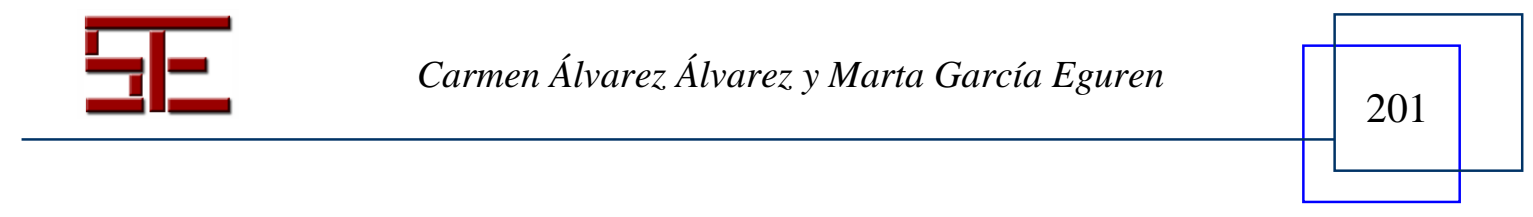




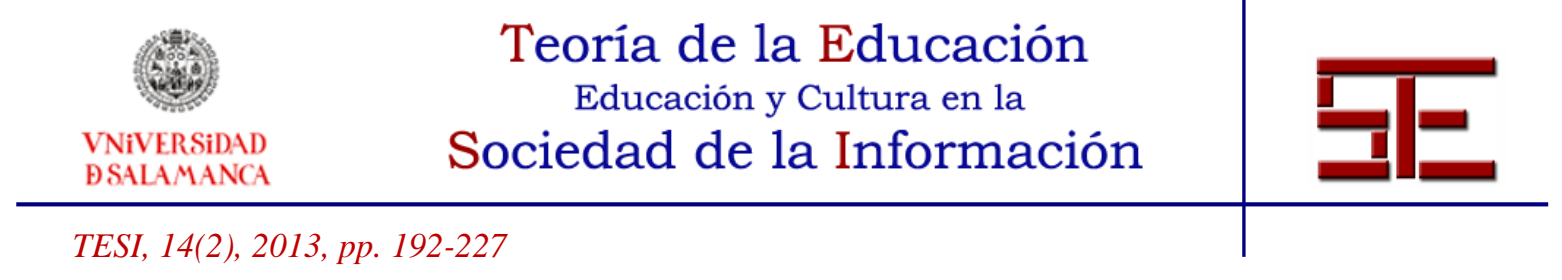

movimiento al propio de la manipulación e interacción con los objetos de la colección del museo presencial.

Desde sus inicios, se ha concebido la página del MERA desde dos dimensiones diferenciadas (Fontal, 2006, 192): como complemento y como extensión del museo presencial. Hasta el momento se ha desarrollado la primera fase del proyecto, correspondiente al diseño y desarrollo de la web, como complemento del museo, permitiendo el acceso a actividades que, por diversas causas, el museo real no puede afrontar. La segunda fase del diseño abordaría el desarrollo de las posibilidades del MERA virtual ${ }^{2}$ en tanto que extensión del MERA presencial, haciendo uso de las posibilidades que ofrece la web, principalmente en lo que a modelo de interacción multidireccional se refiere.

\footnotetext{
${ }^{2}$ En el proyecto de la web se dice: la página ha sido desarrollada íntegramente en lenguaje Action Script por medio del programa Flash 8.El proceso de diseño y desarrollo práctico ha sido largo y ha estado repleto de pruebas y replanteamientos sobre la marcha, lo que es habitual y necesario en todo proceso de creación. El resultado, hoy disponible en la red para cualquier internauta, debe encontrarse en fase de evaluación y constante actualización, puesto que, en tanto que interfaz humano-ordenador, toda página web que ponga en práctica estrategias de diseño novedosas y poco convencionales, está sometida a una constante evaluación de usabilidad por parte de los distintos tipos de usuario. El tipo de interactividad es fijo, ya que se trata en esta primera fase del diseño, de atender las necesidades del MERA en Internet, como complemento del museo presencial y esbozo de sus posibilidades como extensión del mismo. El modelo de interacción es unidireccional, puesto que el sistema no se retroalimenta de información emanada por el usuario. Está basado en la posibilidad de acceder a los contenidos del museo mediante la interacción con los objetos de la colección.
}

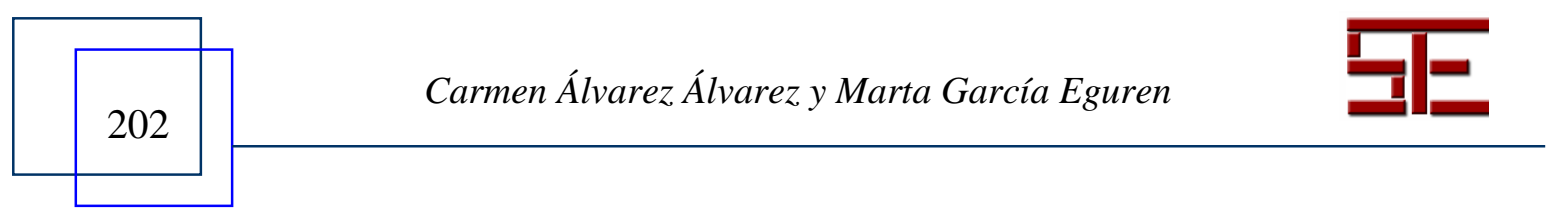



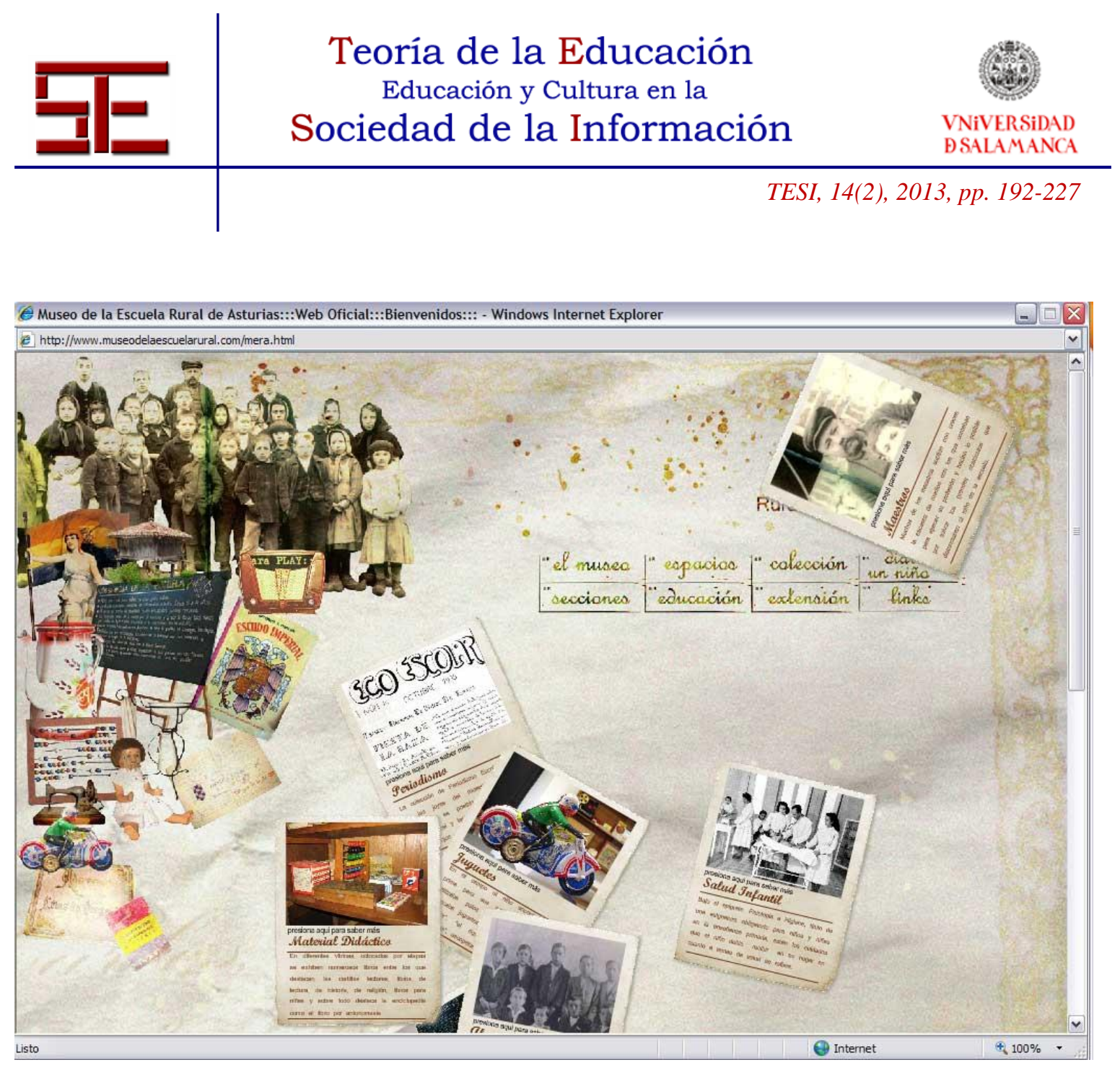

Imagen 1. Página de inicio del MERA, en movimiento.

La finalidad del diseño de la página web del MERA se puede sintetizar en los siguientes puntos:

- Difundir el conocimiento de la Historia de la Educación, rescatando por medio de la investigación testimonios y documentos para hacer partícipe de ellos a la comunidad y a los visitantes: generando vínculos con la comunidad educativa a través de las herramientas didácticas on-line, propiciando situaciones didácticas antes, durante y después de la visita, así como en diferentes ámbitos, principalmente en el profesional, el familiar y el escolar, ampliando el campo de acción cultural y educativa más allá del espacio del museo y a la vez incentivando la visita al mismo y planteando el museo como un espacio para la memoria, la generación de conocimiento y el debate en torno a la educación patrimonial.

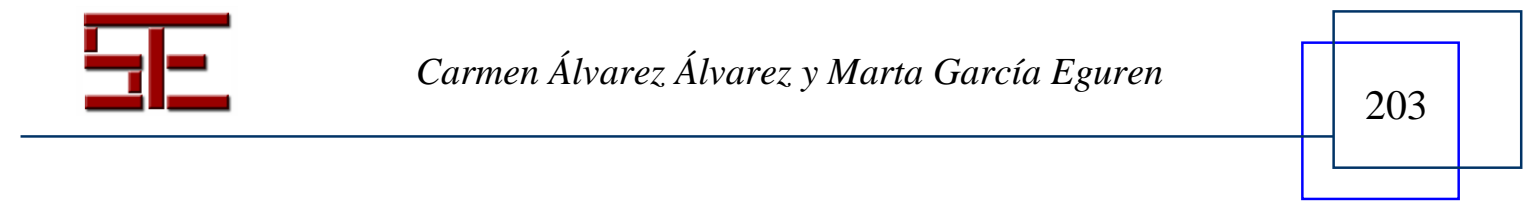




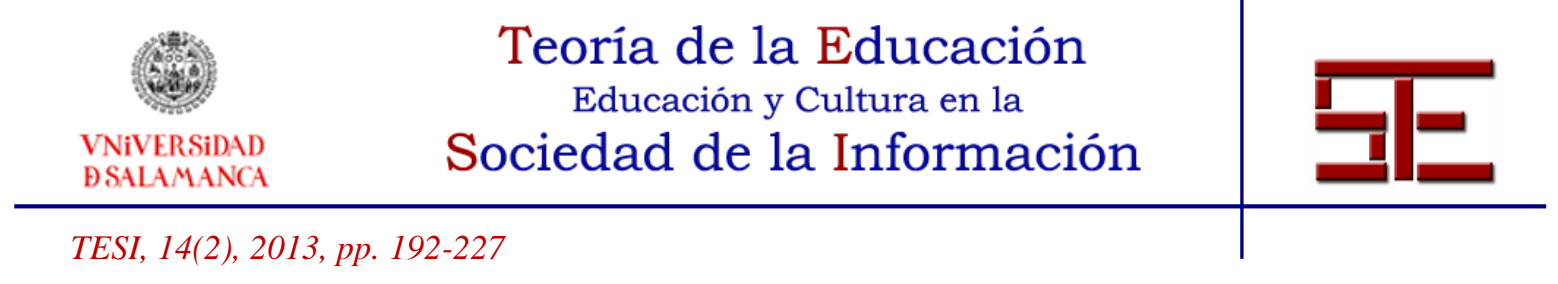

- Transmitir la atmósfera que se percibe en el museo real, cuyo diseño ha sido fiel y respetuoso, tanto con el tratamiento de los contenidos, como con la estética, haciendo partícipe al visitante virtual ${ }^{3}$ de la empatía que desprende la pátina nostálgica que envuelve al museo presencial, tratando de acercar el magisterio a través de los testimonios que maestros y maestras han ido dejando, en el recuerdo de su alumnado y a través de fuentes escritas.

\subsubsection{Punto de partida de la página web}

La página web se acerca al mundo infantil, en el medio rural asturiano desde comienzos del siglo XX. Partiendo del mundo escolar, narra la lucha por conseguir la primera escuela del concejo, cómo fue ésta cuando se creó y cómo, según los criterios higienistas de la época, debía haber sido. También aborda cuáles eran las materias que según el Ministerio de Instrucción Pública se debían impartir y qué formación recibía el alumnado de la época. Así mismo, deja patente la lucha de los maestros y maestras y las autoridades para paliar el alto absentismo escolar. La web refleja que el niño y la niña eran requeridos en el hogar como mano de obra imprescindible y las difíciles condiciones de vida que el entorno del hogar procuraba a la infancia. La página retrata un medio donde se deja ver claramente cómo los niños y las niñas no son las protagonistas, aprendiendo de los mayores desde la cuna y mezclando juegos y trabajo, sin poder poner una frontera muy clara de dónde acaba uno y empieza el otro, asumiendo tempranamente el rol que les tocará desempeñar en el futuro. Para dar una mayor cercanía al usuario de la web, se han incluido documentos y testimonios reales (obtenidos por medio de entrevistas) e historias ficticias basadas en hechos reales (López, Elola y García, 2011).

Marianita, Emilio, María y Pepín, los personajes protagonistas del material didáctico del museo en su versión presencial (Guía para familias), están reflejados en la página web del museo, y están inspirados en personajes reales, tanto en su historia personal, como en el parecido físico, ya que la diseñadora se inspiró para su creación en fotos de exalumnos y exalumnas expuestas en el museo. Los personajes van acompañados de una pequeña biografía, que podría resultar cierta, la cual aporta datos sobre su realidad para acercar ésta a los más pequeños y así, al igual que ocurre en el museo, crear diferentes niveles de

\footnotetext{
${ }^{3}$ En el diseño de la página web se intentó realizar actividades on-line desde el museo, pero no fue posible porque éste carecía de conexión a Internet. A pesar de que el municipio de Cabranes estableció un servicio de red inalámbrica, debido a la orografía, no cubría la zona en la que se ubica el centro.
}

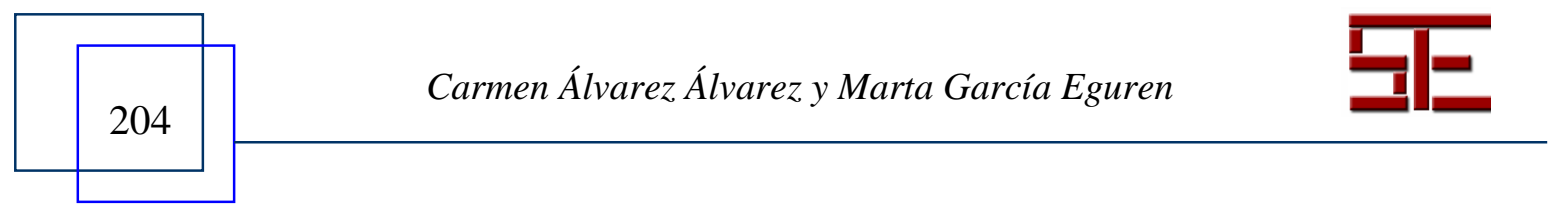




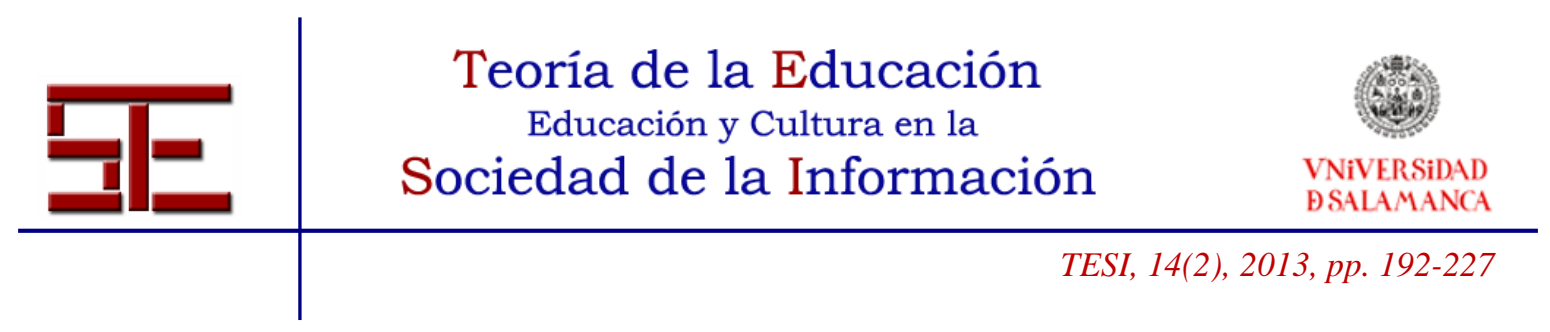

lectura. En el museo real, estos personajes fueron diseñados para hacer una reproducción en madera y ser colocados en puntos estratégicos del museo, buscando la identificación con el público infantil para servir como hilo conductor a la visita, del mismo modo que en la versión web.

\subsubsection{Estructura de la página}

El esquema seguido para la realización del diseño de la página web del MERA se divide en ocho apartados: El Museo, Espacios, Colección, Diario de un niño, Secciones, Educación, Extensión y Links, cada uno de los cuales representa un itinerario de acceso a los contenidos del museo virtual. Los apartados Espacios, Colección, Diario de un niño y Secciones constituyen itinerarios distintos, que están interconectados entre sí, de manera que muchos de los contenidos a los que se accede desde cada uno de ellos son compartidos. El usuario puede cambiar, siempre que lo desee, a otro itinerario, ya que están todos disponibles permanentemente en la parte superior de la página.

En formato de cuaderno, inspirado en las libretas escolares, se comentan los puntos básicos de un día en la escuela, que comprende el itinerario, la llegada a clase y las tareas habituales que se desarrollaban dentro del aula. Para ello se han usado testimonios recogidos por medio de entrevistas efectuadas a exalumnos de las etapas republicana y franquista, quedando definidos y representados los roles masculino y femenino. Los testimonios van unidos a fotografías de piezas del museo y a un archivo sonoro donde se pueden escuchar con su propia voz. En diferentes epígrafes de la página web se refleja la información extraída de fuentes primarias, unidas a otras informaciones provenientes de fuentes bibliográficas, que ayudan a acercar al niño de otras épocas en el entorno rural, al visitante.

La web se estructura a su vez en dos recorridos: (a) Recorrido basado en contenidos y (b) Recorrido basado en el Diario de un niño. A continuación detallamos los contenidos de cada uno de ellos:

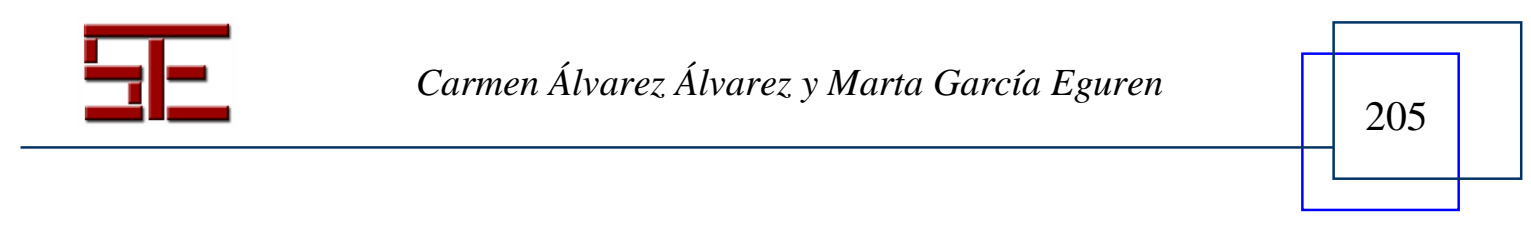




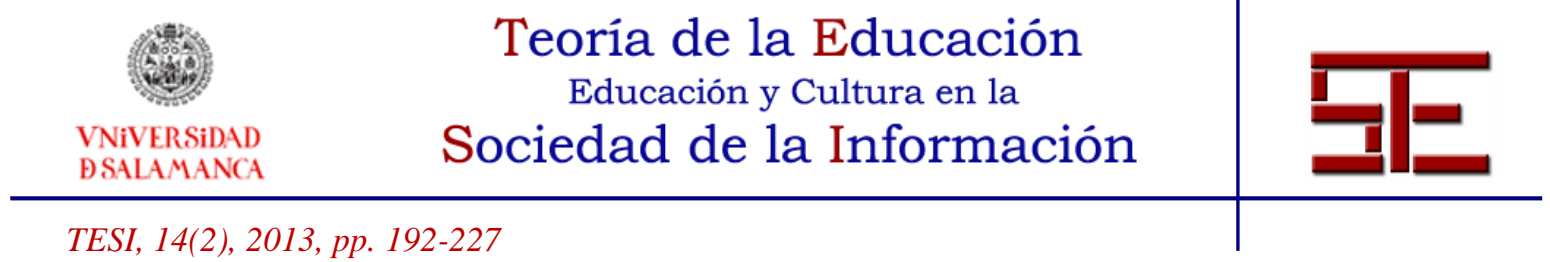

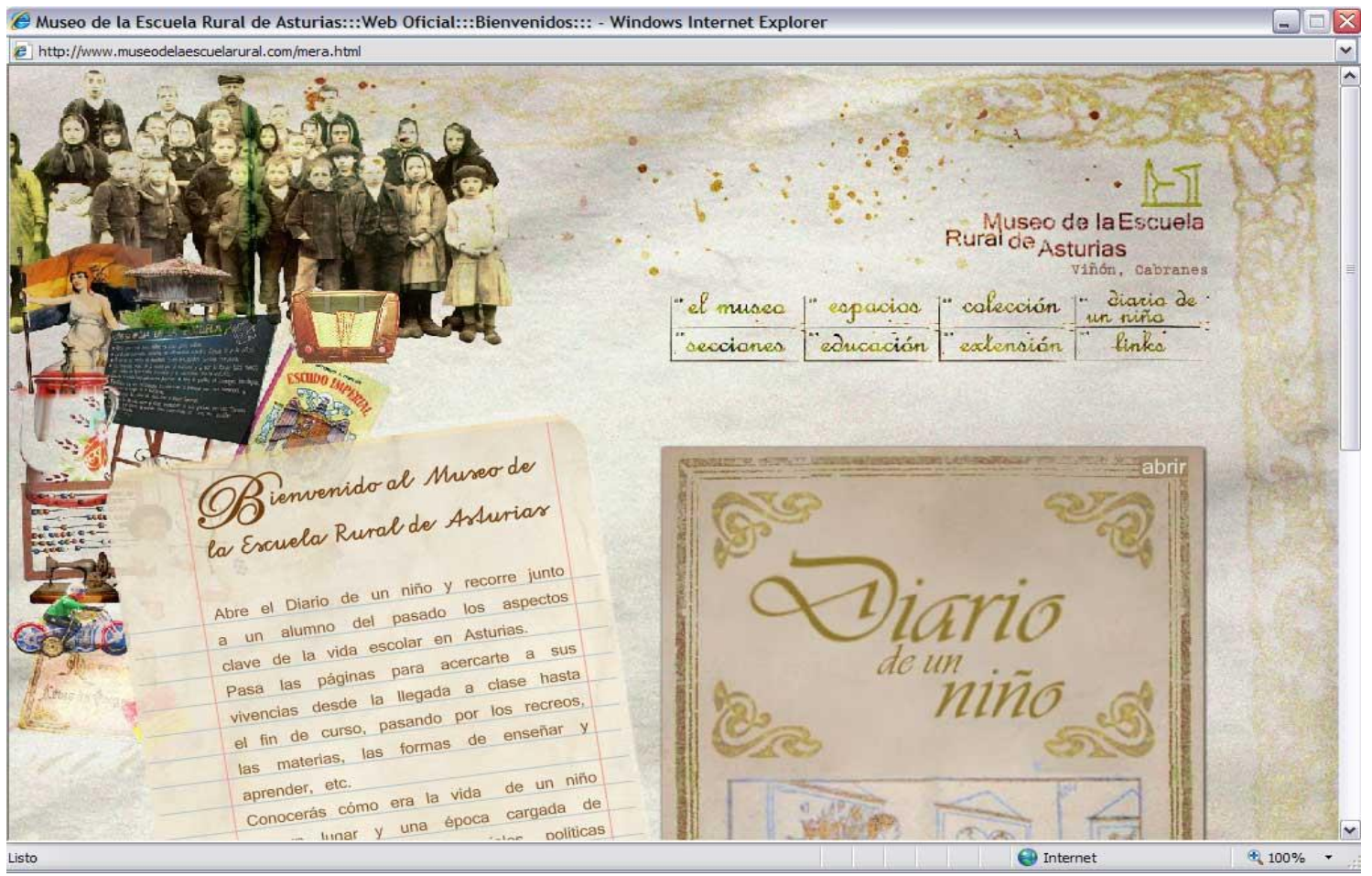

Imagen 2. Página de inicio web del MERA.

\section{A) Recorrido basado en contenidos:}

- El Museo: Cumple la función de aportar información general antes de la visita. Es de utilidad especialmente para el público especializado, ya que incluye un formulario de contacto, que abre una vía de comunicación entre el museo y el público virtual. Ofrece también una introducción al museo desglosada en: objetivos, historia de la escuela (19081970), historia del museo (2001-2007), trayectoria, y personajes clave, tanto para la fundación de la escuela, como para el posterior nacimiento del museo. Así mismo incorpora el vídeo promocional del museo.

- Espacios para conocer y aprender: En paralelo a la estructura que encontramos en el museo presencial se creó un recorrido por los distintos espacios en los que se divide el museo: Aula Republicana, Aula Franquista, Vivienda del maestro, Sala polivalente, Sala del libro escolar y Desván. Este apartado nos muestra, mediante imágenes y textos dinámicos, los espacios más relevantes que recrea la musealización evocadora del MERA. Cada espacio tiene sus vínculos a dos secciones: No te lo pierdas, donde

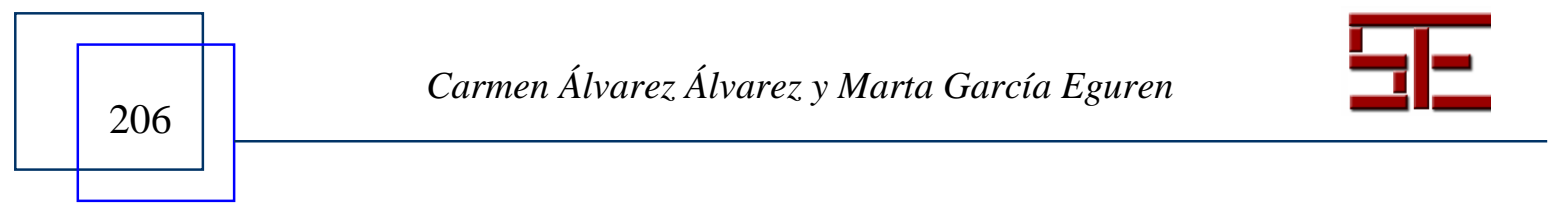




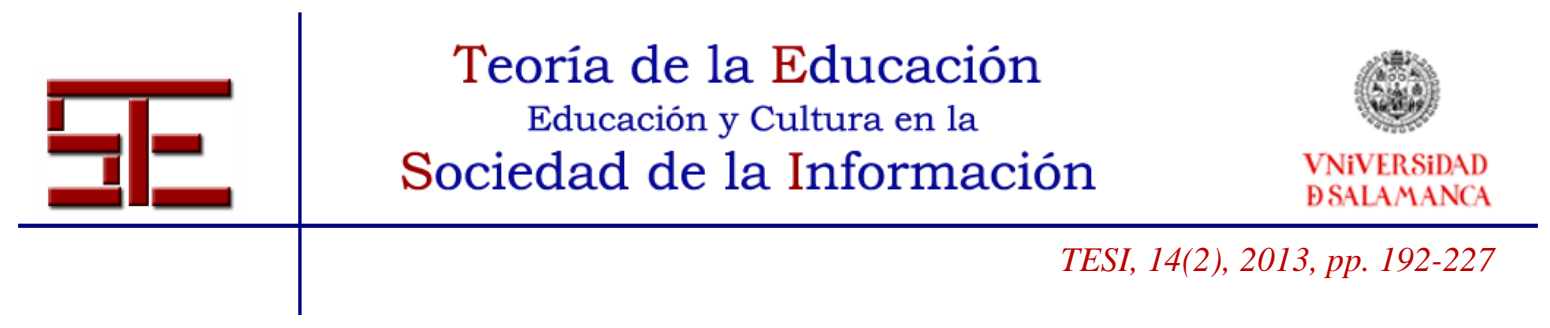

encontrará información imprescindible y Para saber más, sección replicada del museo presencial, que ampliará los conocimientos del usuario, aportando otro nivel de lectura más detallada.

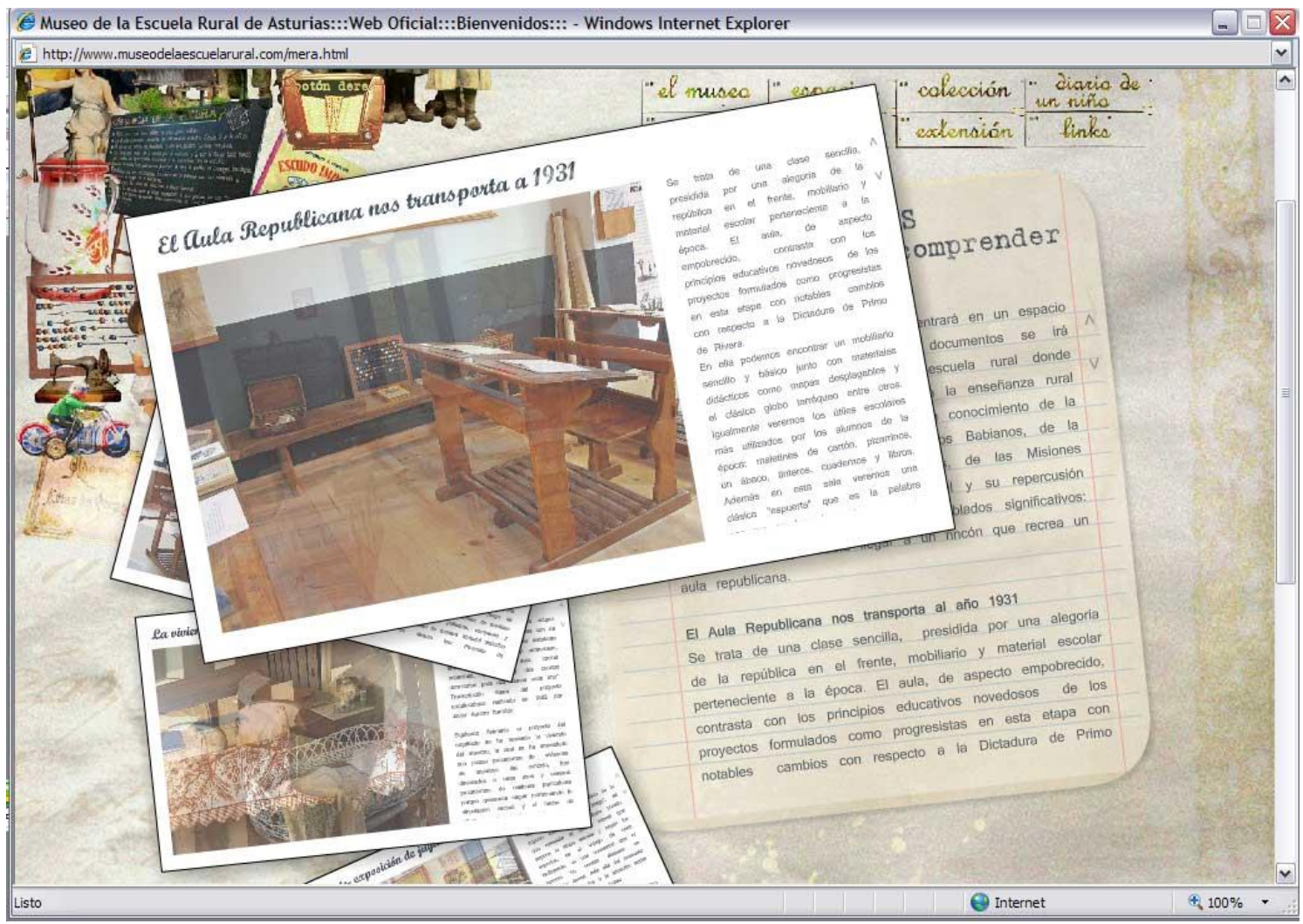

Imagen 3. Espacios.

- Colección: Introduce, a través de una galería de imágenes ${ }^{4}$, en un recorrido por la colección, secuenciando la visita virtual de forma temática: maestros, alumnos, mobiliario escolar, material didáctico, juguetes, salud infantil y derechos del niño.

\footnotetext{
${ }^{4}$ Las fotografías que se incluyen en la página web fueron hechas por la diseñadora de la web, la directora del MERA y dos visitantes aficionados a la fotografía: Juan Carlos Iglesias Rodríguez y Eloy Rodríguez Bajatierra.
}

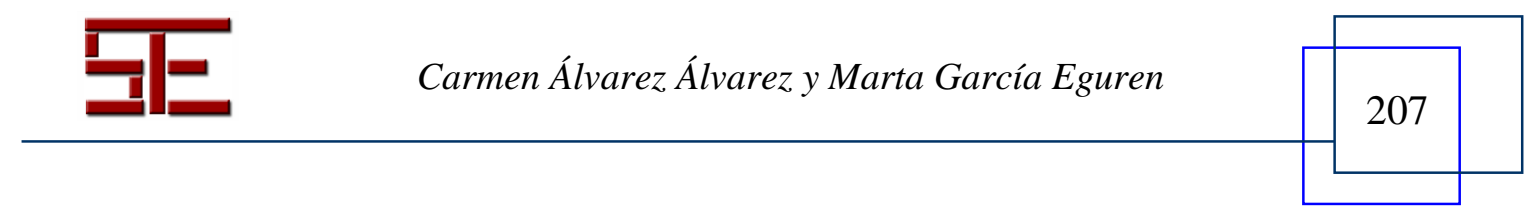




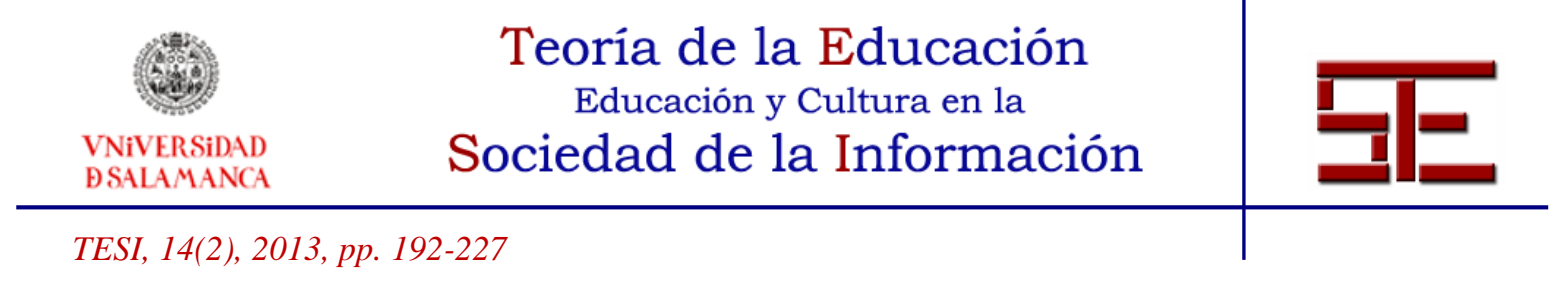

- Secciones: Apartado diseñado para ser sometido a una actualización constante que ofrece al visitante información clasificada en tres secciones: Noticias, Libro del mes, La cocina de la Escuela y Diario de un niño.

- Educación, Estrategias didácticas: Informa al visitante respecto a la política educativa del museo, permitiéndole descargar un material didáctico pre-visita para grupos de estudiantes y dar a conocer el material diseñado para familias durante la visita. Asimismo, insta al usuario a contactar con el museo y a solicitar información relativa a otras actividades como cursos, tertulias y seminarios, por medio del formulario de contacto disponible. En esta sección se facilita la posibilidad de descargar en PDF los siguientes archivos:

- "Periodistas por un día". Material apto para ser descargado por profesores de Secundaria para trabajar antes y después de la visita al museo.

- "La cocina de la escuela". Recetas de cocina extraídas de libros de economía doméstica que las niñas estudiaban como asignatura en la escuela.

- "El libro del mes". Cuyo contenido incluye el comentario ${ }^{5}$ de un libro escolar.

- Extensión: Informa al visitante de las actividades que desarrolla el museo como dinamizador de la vida del municipio: programa de "guías mayores" y recopilación y elaboración de audiovisuales basados en testimonios orales, así como cursos, seminarios $\mathrm{y}$ otras actividades que puedan darse en el escenario del museo o gestionadas por el mismo.

- Links: Ofrece vínculos a direcciones de Internet relacionadas con la museografía escolar, la etnografía y la Historia de la Educación.

La página está dotada de sonido. Se ofrece la posibilidad de ambientar la visita con música. En la página de inicio hay una radio antigua, réplica de la que hay en el museo, que se encuentra en la sala de la casa del maestro y contiene música clásica. También es posible escuchar varios testimonios orales de exalumnos de la escuela, asociados a los contenidos a los que se accede desde cada apartado, que han sido extraídos de los audiovisuales que se pueden visionar en el museo: "Historia de una escuela-Cabranes 1900-1970” y "Maestros de la Escuela Rural de Asturias".

${ }^{5}$ Consideramos que la actualización mensual de la sección serviría para establecer lazos de unión con el visitante virtual.

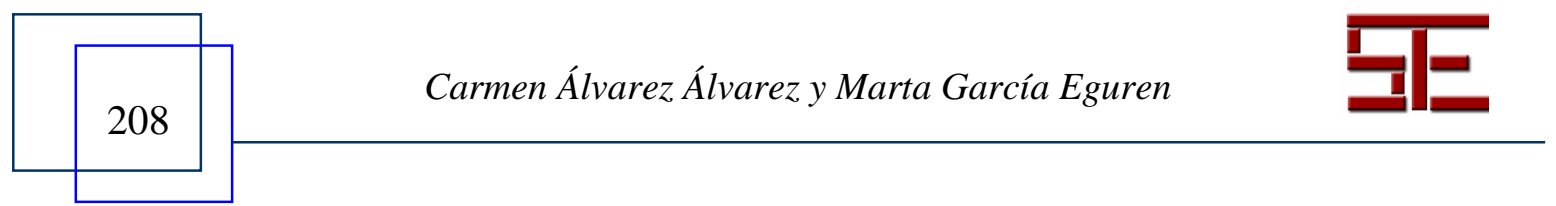




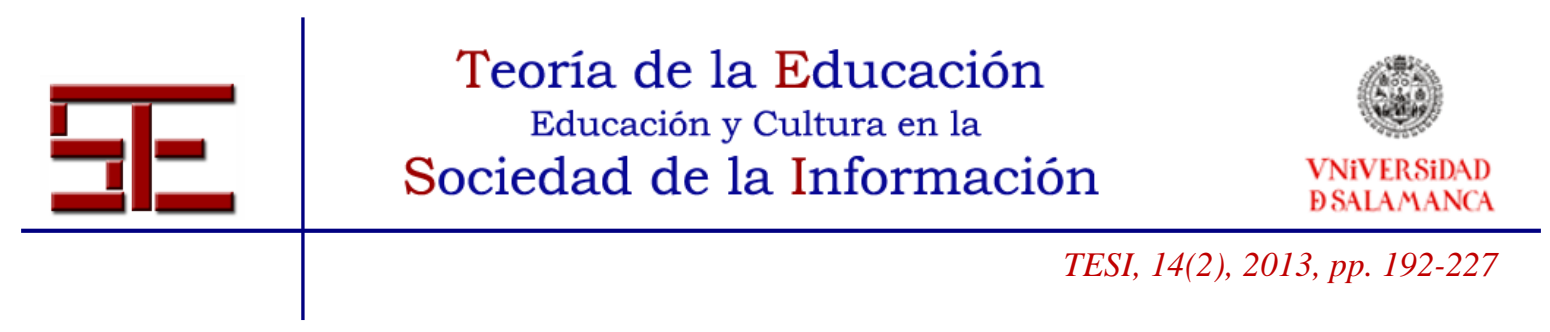

Así mismo la página, tal como hemos referido anteriormente, incorpora varios audiovisuales. Se ha incluido un vídeo promocional, rodado en el museo, contando con personas mayores y niños del municipio, en el papel de actores, que una vez más dan cuenta a través de su interpretación de cómo era la vida en la escuela. El audiovisual tiene diversos niveles de lectura, siendo accesible al público que no tiene conocimientos sobre la vida en la escuela rural y, especialmente al público infantil.

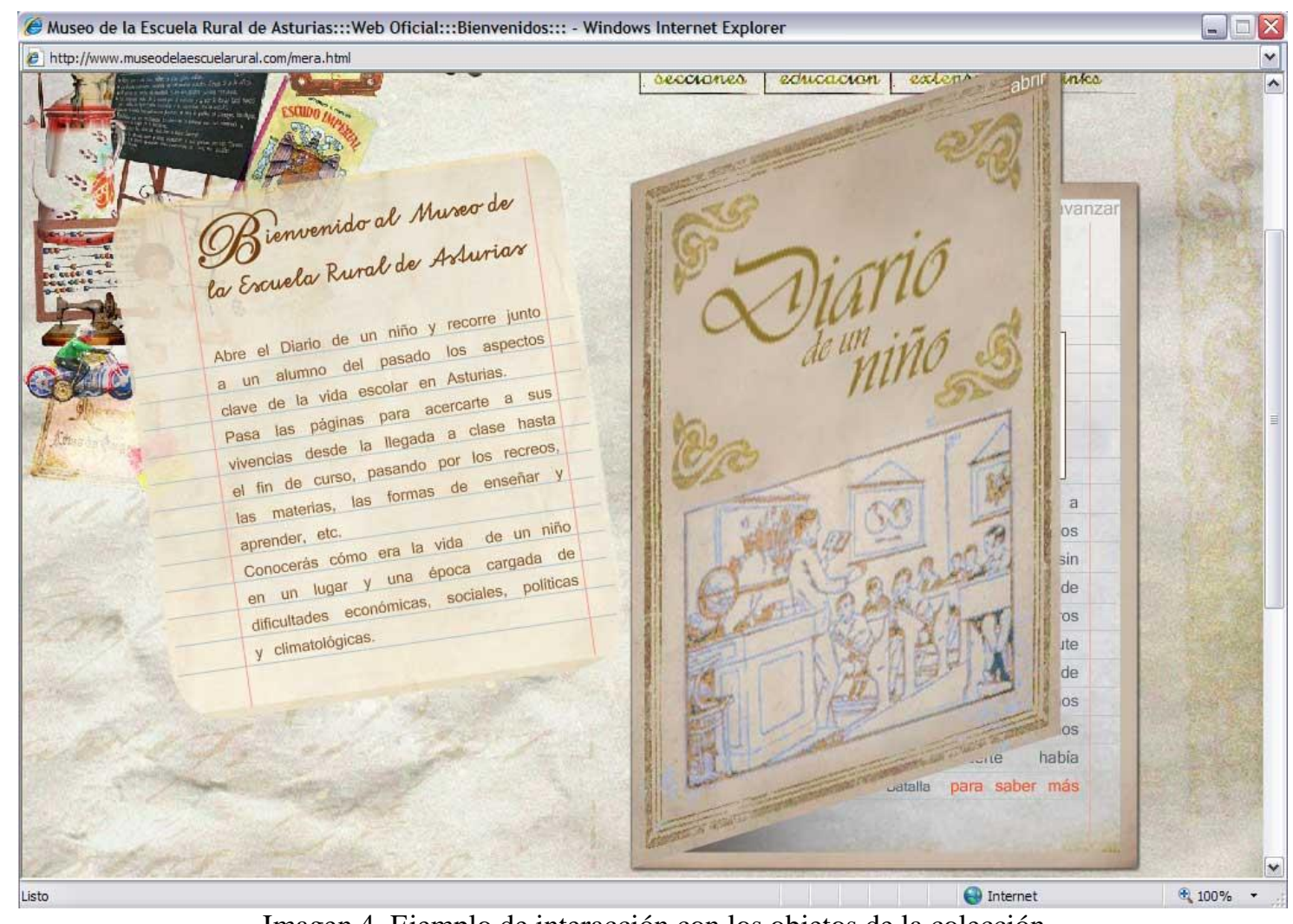

Imagen 4. Ejemplo de interacción con los objetos de la colección.

\section{B) Recorrido basado en el Diario de un niño:}

- Diario de un niño: Nos invita a conocer, a través de sus páginas y los testimonios sonoros de los antiguos alumnos incluidos en ellas, cómo era la vida de los alumnos del pasado de esta escuela a lo largo del tiempo: la vida en familia, el camino a casa, las diferentes formas de trabajar en el aula, la evolución de los materiales didácticos, etc. El diario, basado en recuerdos reales, está desglosado en las siguientes secciones:

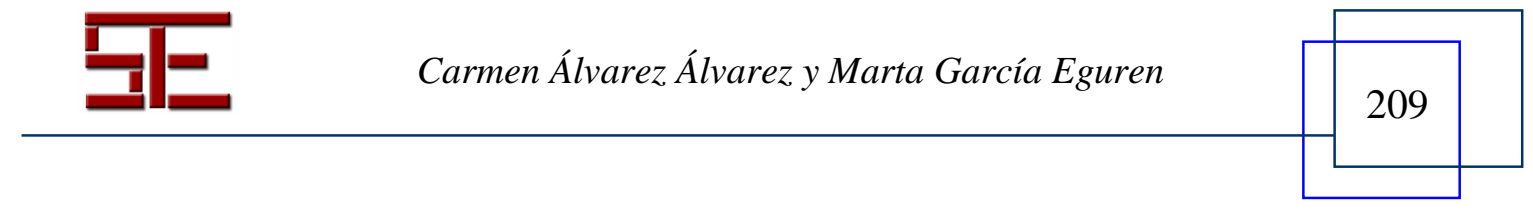




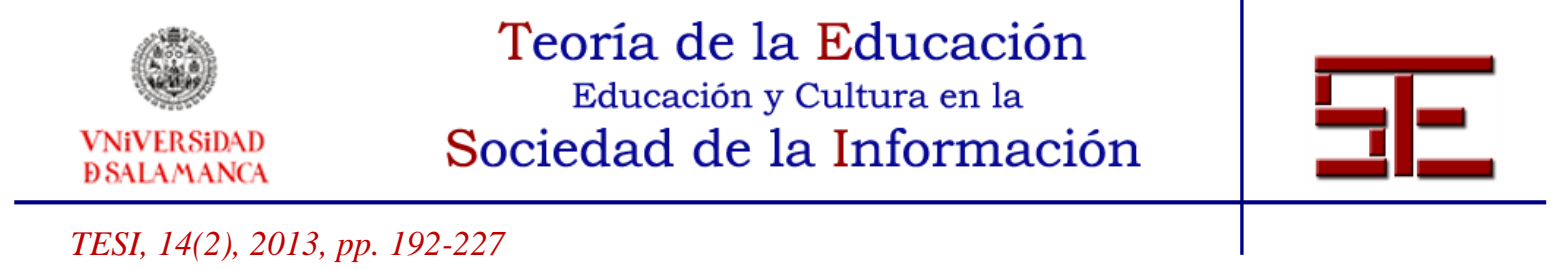

- Camino a la escuela: esboza la vida infantil poniendo en relación el hogar y la escuela, la vida en familia, los cuidados que el niño recibe en casa y el trabajo que debe desempeñar en ella.

- Llegada a clase: nos presenta al alumnado vestido y calzado para ir a la escuela portando su pequeña cesta de comida y el comienzo de la jornada escolar.

- De la pizarra a la libreta: la escritura, y sus diferentes formas es la protagonista de este apartado, que pone de manifiesto la importancia de todo aquello que debía pasarse a la libreta para ser aprendido y recordado.

- Trabajo conjunto: en este apartado quisimos destacar una pieza clave del museo: el periodismo escolar, trasladando la importancia que el documento posee al terreno virtual, para ilustrar el trabajo en equipo, que se completa con la libreta de rotación.

- Materias: las asignaturas consideradas prioritarias tenían asignado un día de la semana, así como libros y material asociado a cada una de ellas. Esta asociación de elementos se refleja en la página y establece la comparación con la llegada de la enciclopedia, libro por antonomasia en el universo de la escuela rural.

- El recreo: se reconstruye el tiempo y el espacio del recreo con música, juegos y juguetes, basados en testimonios orales aportados por los informantes.

- Fin de curso: la presencia del fotógrafo se hacía sentir excepcionalmente en fechas próximas a la llegada del fin de curso, por este motivo, en el último apartado del diario se incluyen fotos comentadas, cargadas de significado. Los boletines de notas y la mención de premios y castigos completan este señalado momento y sirven de cierre al apartado.

A través de la página también se facilita el acceso a documentos e información complementaria para que el visitante virtual pueda conformar sus propias conclusiones.

\subsection{Evaluación}

Cuatro años después de abrir al público la página web del MERA en Internet tiene interés conocer la vigencia de la página y su potencial para atraer a un público diana, como son los estudiantes de Magisterio. Para ello se ha elaborado una investigación mediante cuestionario, cuyo propósito es sondear la opinión de un grupo de estudiantes

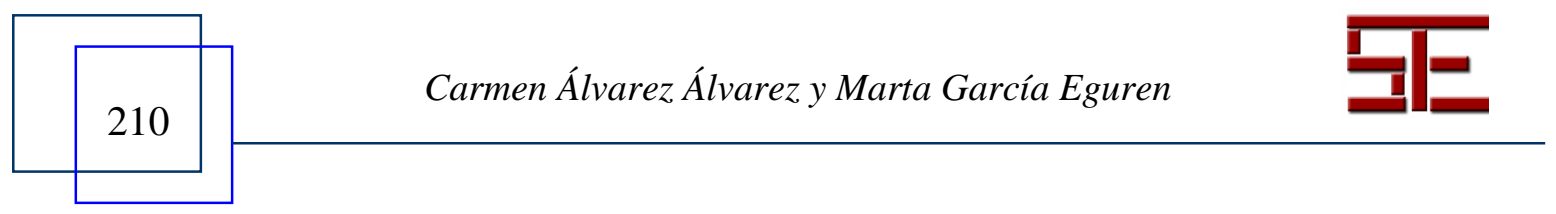




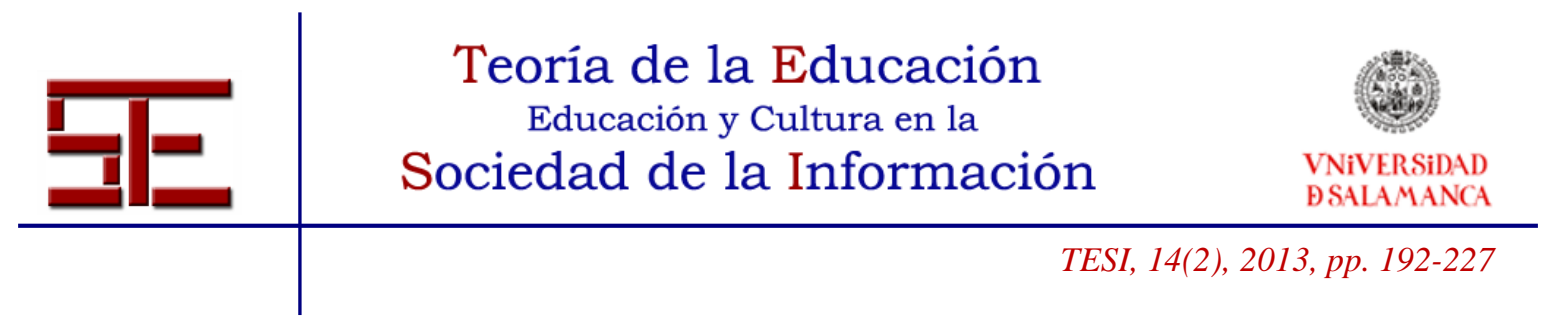

pertenecientes Magisterio por la especialidad de Educación Primaria de la Universidad de Oviedo, respecto a aspectos formales, funcionales y conceptuales de la página.

Para realizar el cuestionario se han consultado varios trabajos de investigación en Didáctica de las Ciencias Sociales, entre los que destacamos el trabajo teórico de Cuenca (2003) sobre la necesidad de una formación mucho más práctica para el profesorado, utilizando la enseñanza informal. También hemos recurrido al posterior trabajo de Calaf (2009), que se sustenta en el marco teórico ofrecido por Cuenca y tiene como marco aplicado de estudio empírico el MERA, desde el que se investiga sobre las concepciones de dos grupos implicados en el proceso educativo: los estudiantes de Magisterio y el profesorado en formación continua. Calaf (2009) realizó una investigación recabando las expectativas de sus estudiantes de Magisterio sobre el MERA y luego organizó una visita al mismo. Tras esto, puso las expectativas de los estudiantes en relación con su satisfacción con la visita al MERA, descubriendo una notable relación de coherencia entre expectativas y resultados. Su investigación se enmarca dentro de la línea de estudios vinculados a la formación inicial, donde se sitúa el museo como un recurso para el aprendizaje.

En nuestro caso, el interés del estudio evaluativo sigue, en cierto modo, la línea iniciada por Calaf. Nuestra pregunta de investigación es: después de visitar la web del MERA en Internet, ¿mantiene su vigencia y su potencial para atraer a un público diana como son los estudiantes de Magisterio?

\subsubsection{Diseño del estudio evaluativo}

El estudio sigue el modelo de investigación evaluativa de corte cuantitativo. Por su profundidad u objetivo podemos clasificarlo dentro de la investigación descriptiva, puesto que trata de conocer la situación actual. En el proceso se ha contado con la ayuda del paquete estadístico SPSS 17.0 y el programa Excel. La clasificación del estudio se detalla a continuación.

\begin{tabular}{|c|c|}
\hline $\begin{array}{c}\text { Tipo de estudio } \\
\text { respecto a: }\end{array}$ & Clasificación del estudio realizado en el MERA \\
\hline Finalidad & Básica \\
\hline Objetivo & Investigación descriptiva \\
\hline Medida & Cuantitativa \\
\hline Marco & Laboratorio \\
\hline
\end{tabular}

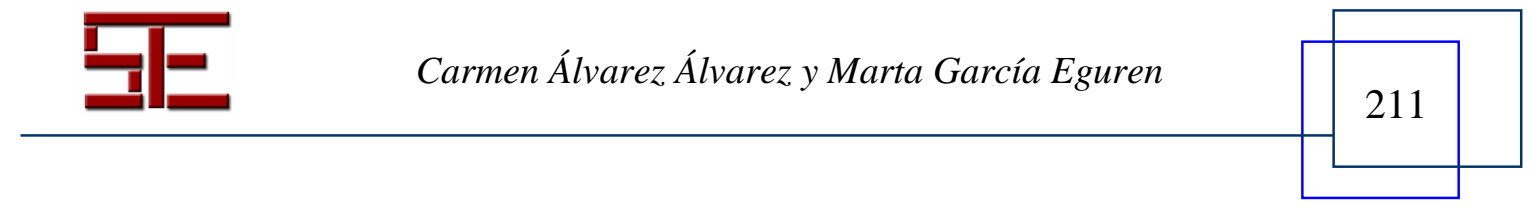




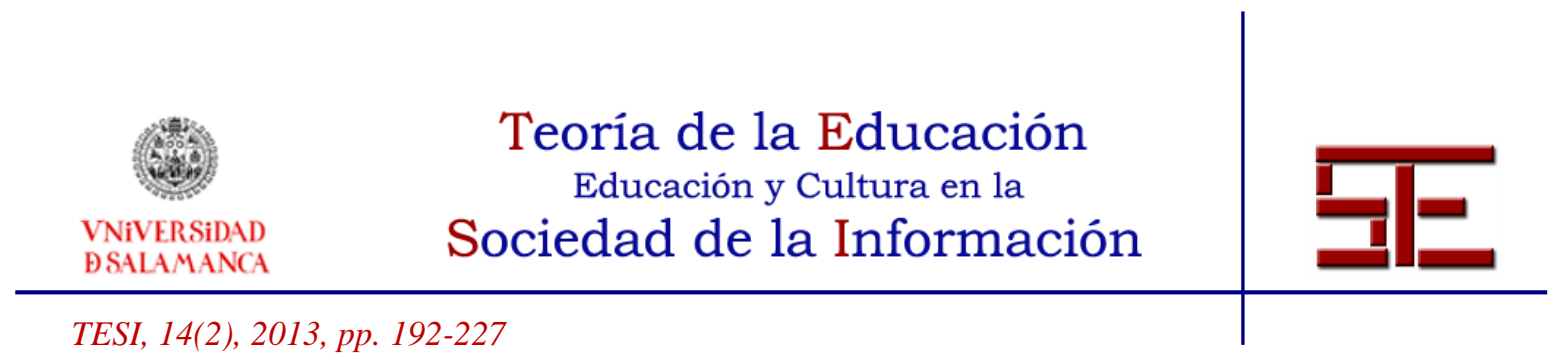

\begin{tabular}{|c|c|}
\hline Concepción & Nomotética \\
\hline Dimensión temporal & Descriptiva \\
\hline Variables & Cualitativas dicotómicas y cuantitativa discreta \\
\hline
\end{tabular}

Tabla 1. Clasificación del estudio.

En el Gráfico 1 podemos observar la secuencia seguida en el desarrollo del proceso de evaluación:

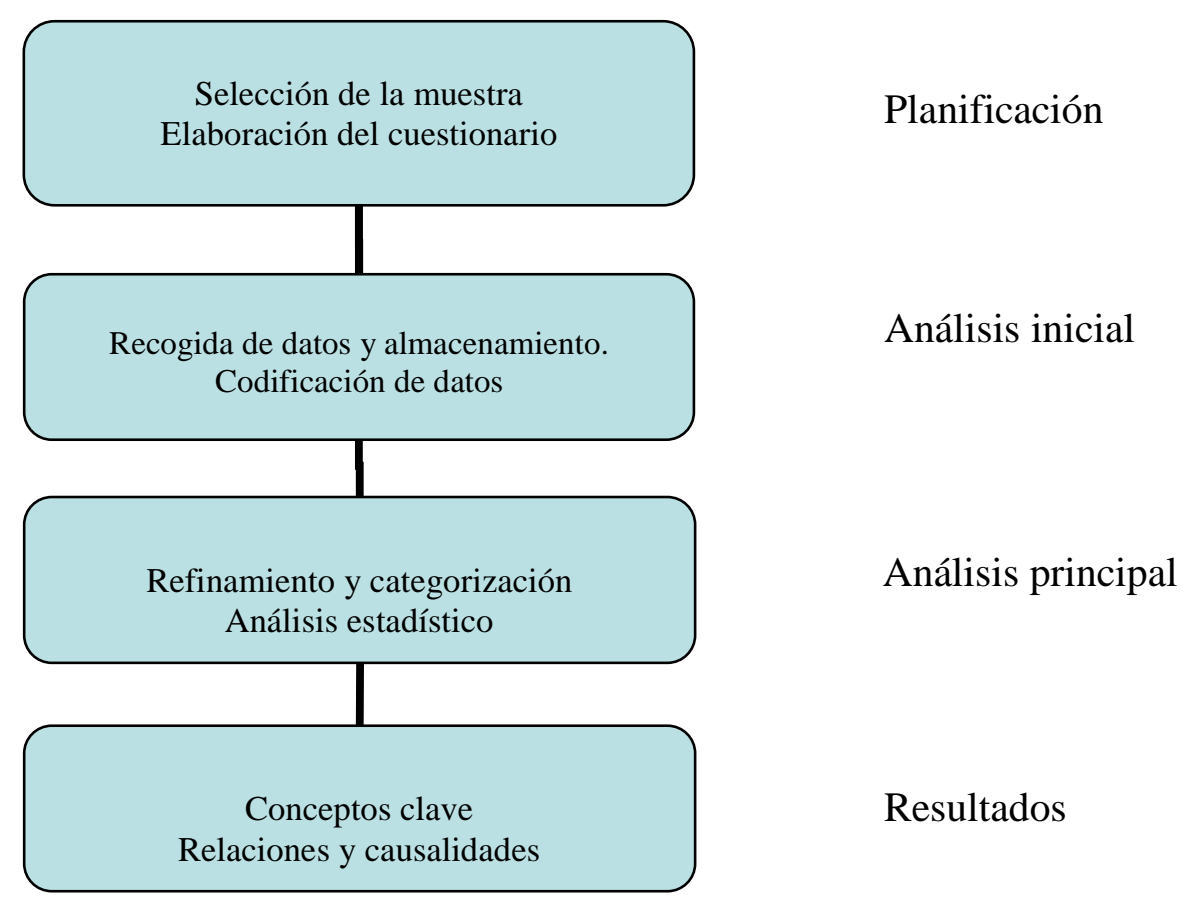

Gráfico 1. Secuenciación de las fases del proceso de investigación.

\subsubsection{Selección de la muestra}

La muestra se compone de veintinueve personas, todas ellas alumnos y alumnas de la asignatura Didáctica de las Ciencias Sociales, que imparte la profesora Roser Calaf, dentro del programa de estudios de la titulación de Magisterio por la Especialidad de Educación Primaria, en la Escuela Universitaria de Magisterio de la Universidad de Oviedo.

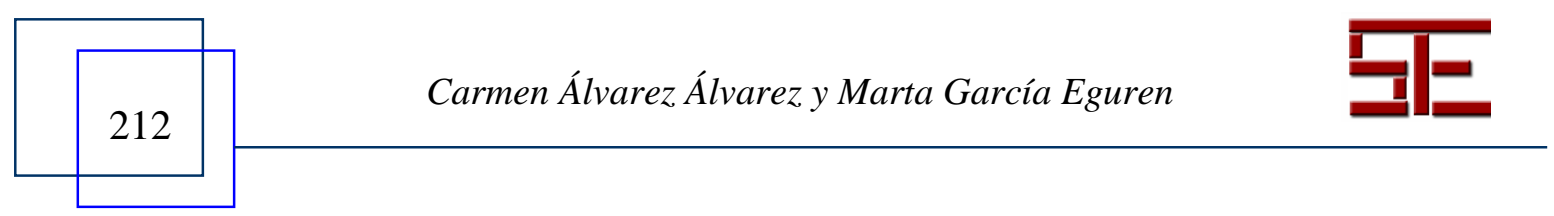




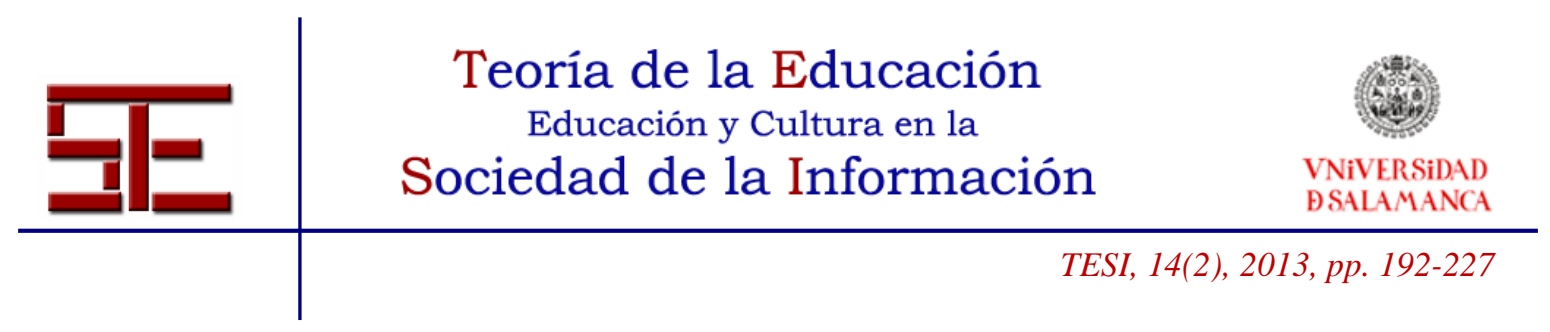

La muestra está compuesta en su mayoría por mujeres, como es habitual en este tipo de estudios: más de un $80 \%$ por ciento, mientras que un $17,2 \%$ son hombres, todos ellos estudiantes de tercer curso de diplomatura. La edad de los estudiantes se sitúa entre los 19 y los 44 años, siendo la media de 23,1, la moda 20 y la mediana 20.

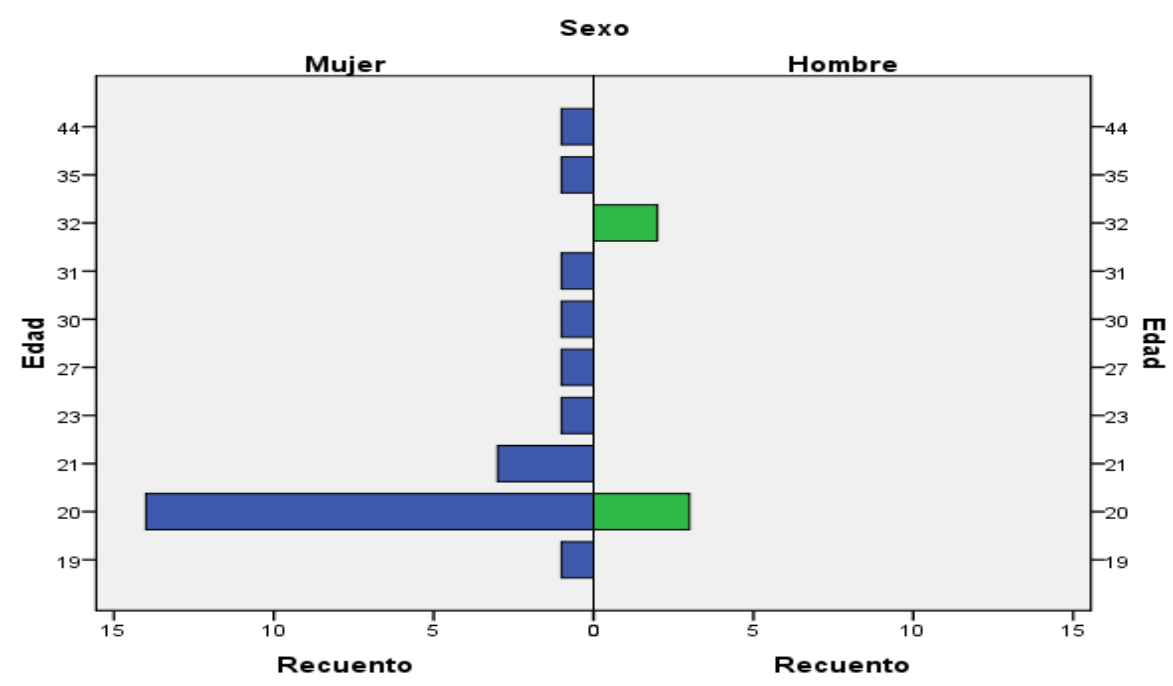

Grafico 2. Pirámide de sexo y edad de los participantes en la muestra.

En nuestra investigación no deseábamos tener una amplia representatividad del estudiantado, crear sistemas de selección de la muestra, ni llegar a todos los grupos de estudiantes de la facultad. Nuestro interés investigador se limita a conocer cómo un grupo de estudiantes en formación en Didáctica de las Ciencias Sociales entiende el diseño e implementación de la web de un Museo Pedagógico para conocer su opinión sobre la misma y acercársela como fuente de recursos útil para su desarrollo profesional futuro, en línea con la investigación previa realizada por Calaf (2009), ya que dos personas de su grupo de investigación se encontraron ligadas al diseño y desarrollo de la página web. En este sentido, no es nuestro objetivo en este trabajo establecer conclusiones generales ni generalizables. Por el contrario, consideramos que la finalidad última de este estudio es abrir un espacio para nuevas líneas de investigación, que permitan continuar desarrollando el trabajo previo, reflexionando sobre las formas de percibir, apreciar y conceptualizar diferentes aspectos, que resultan relevantes para mejorar el conocimiento del binomio público especializado-museo y el binomio público general-museo, a través de la página web.

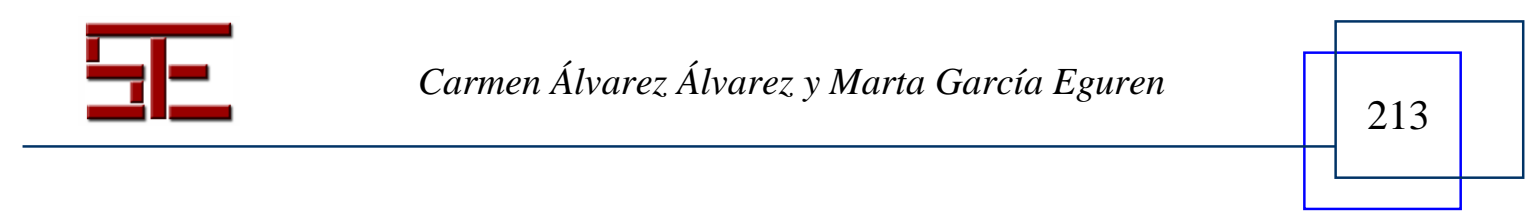




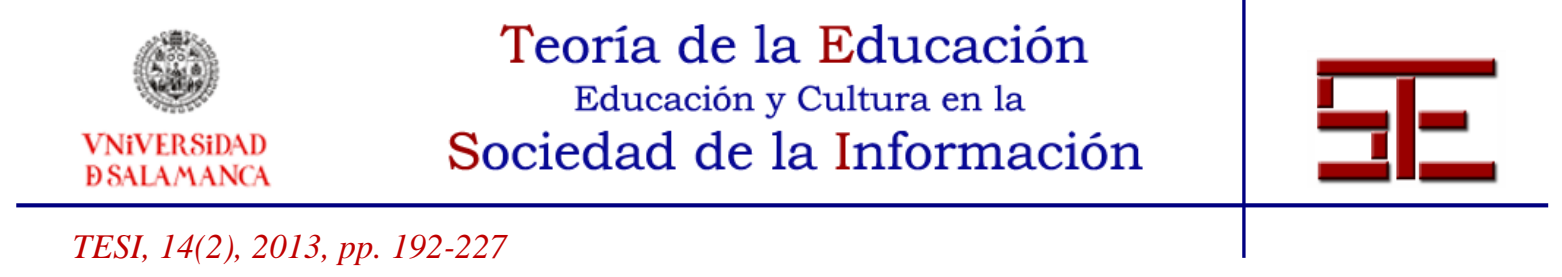

\subsubsection{Cuestionario}

El cuestionario que se pasó a los estudiantes consta de nueve preguntas con las que se pretende recoger la percepción sobre la página web del museo, agrupadas en diferentes bloques temáticos, con preguntas de carácter genérico y específico, para sondear la opinión de los estudiantes en tres grandes apartados:

- Imagen y comprensión.

- Conceptos: cambio y continuidad respecto a la enseñanza en otros periodos y la actual.

- Expectativas sobre el MERA.

Las preguntas incluidas en el cuestionario solicitan una opinión sobre el diseño de la página, así como sobre sus contenidos, tratando de averiguar si resultan adecuados y de utilidad para el nivel de conocimientos de este colectivo.

La dirección de la página web y el cuestionario fueron entregados por la profesora Roser Calaf, quien amablemente accedió a colaborar en esta investigación, solicitando a sus estudiantes una navegación personal en privado y la respuesta voluntaria del cuestionario. Respondieron al mismo veintinueve personas de un total de treinta y nueve matriculados en la asignatura.

\subsubsection{Análisis de los datos}

Los datos arrojan luz sobre las variables previamente comentadas: diseño, conexión de la web con el pasado escolar rural, etc. A continuación comentamos los resultados más destacados al respecto, mostrando los datos en los que nos basamos para realizar tales afirmaciones.

\section{- Diseño de la página web}

A la pregunta sobre si es de su agrado el diseño de la página, el 86,2\% contestó de manera afirmativa, mientras que el 13,8\% de los encuestados respondió lo contrario.

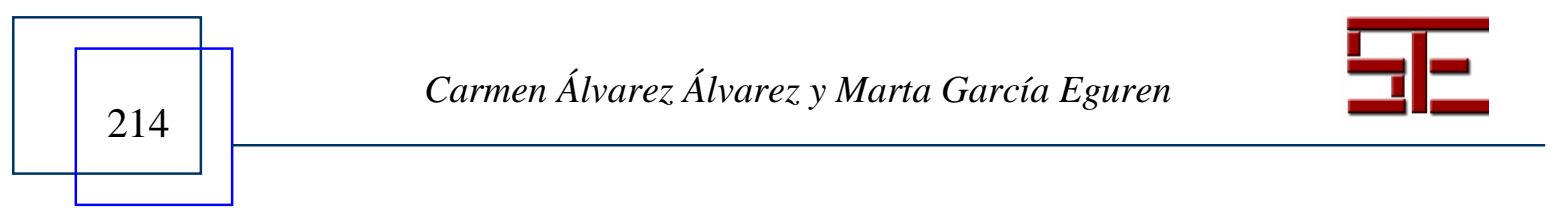



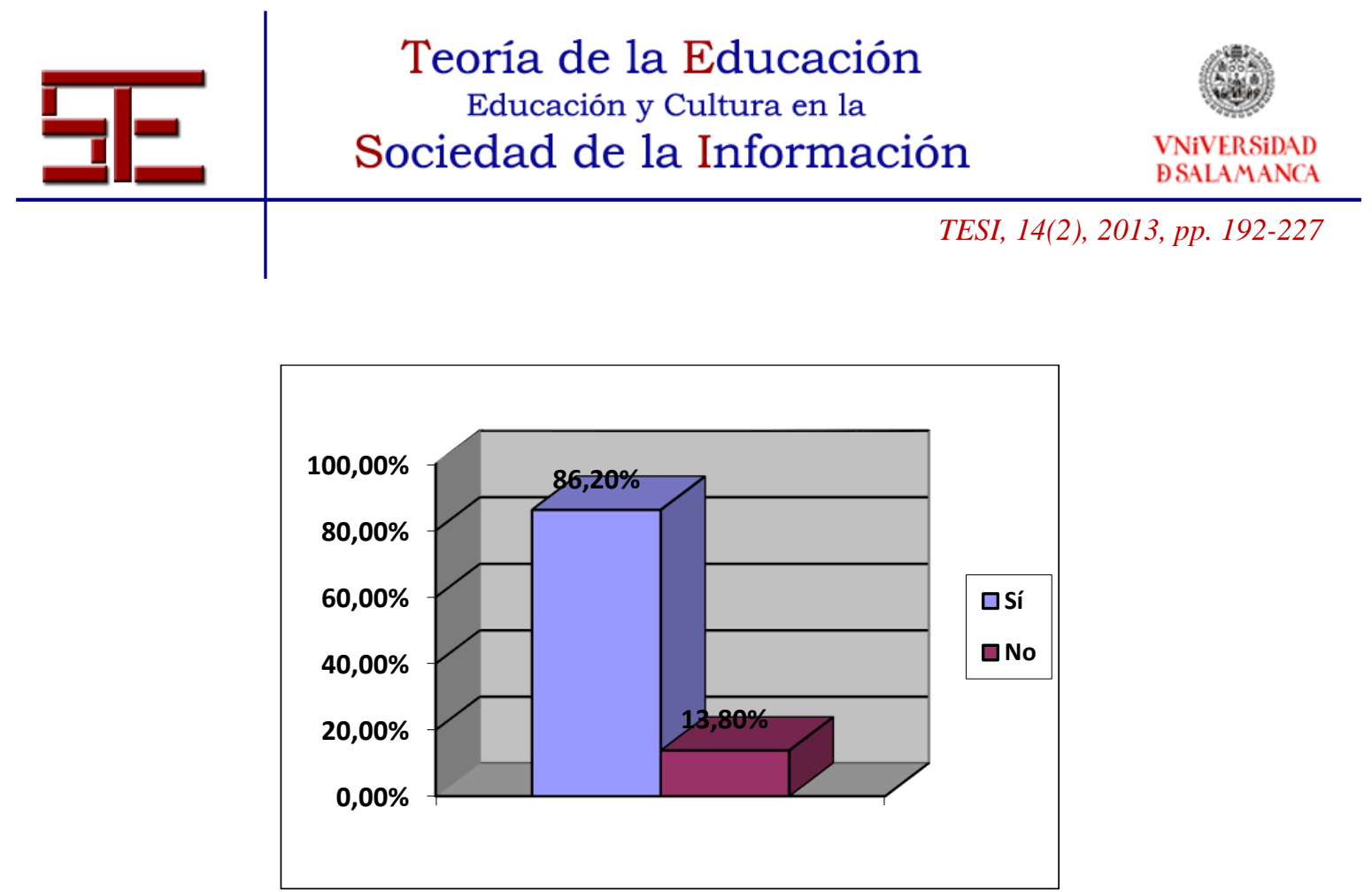

Gráfico 3. Agrado con el diseño de la web.

Esto nos conduce a pensar que el diseño de la web sigue siendo atractivo en la actualidad, lo cual no significa que sea un resultado definitivo, sino que las personas que gestionan en la actualidad el museo y la página web deberían seguir valorando esta dimensión para incorporar novedades, que son inherentes a una página web viva, porque ésta es en cierto modo un detector de la "salud" del propio museo, llegando incluso a convertirse en su "marca".

\section{- Conexión de la web con el pasado}

El 82,8\% de los encuestados consideran que la estética de la página conecta con el pasado y el $17,2 \%$ opinan lo contrario.

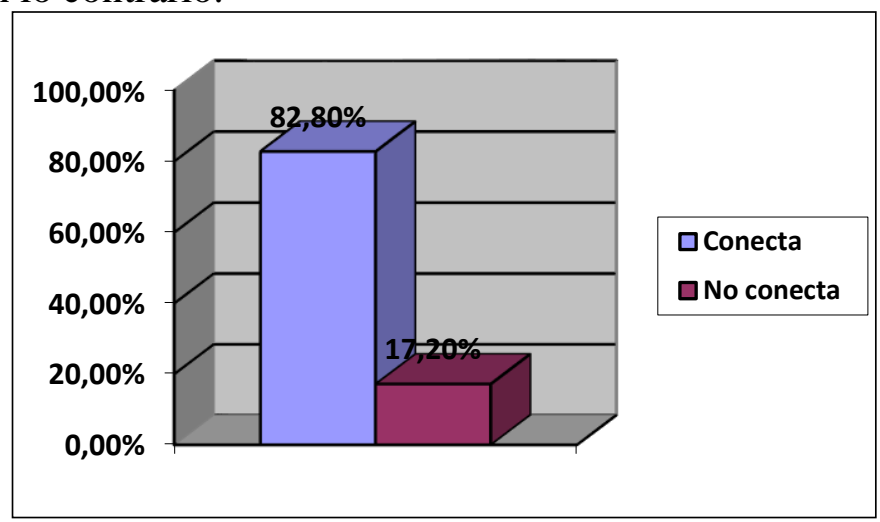

Gráfico 4. Conexión de la web con el pasado.

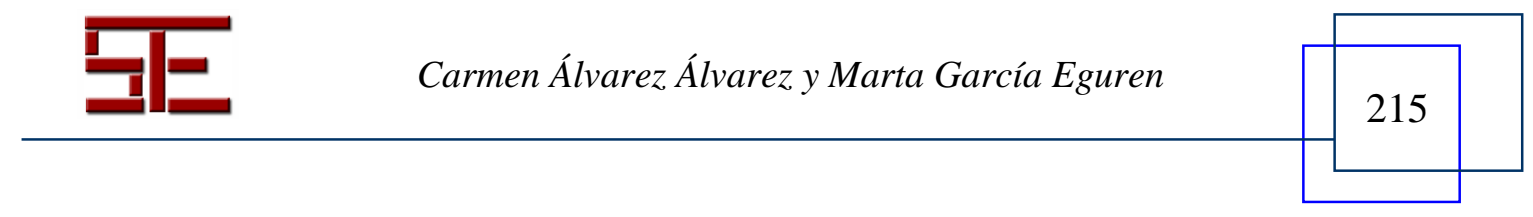




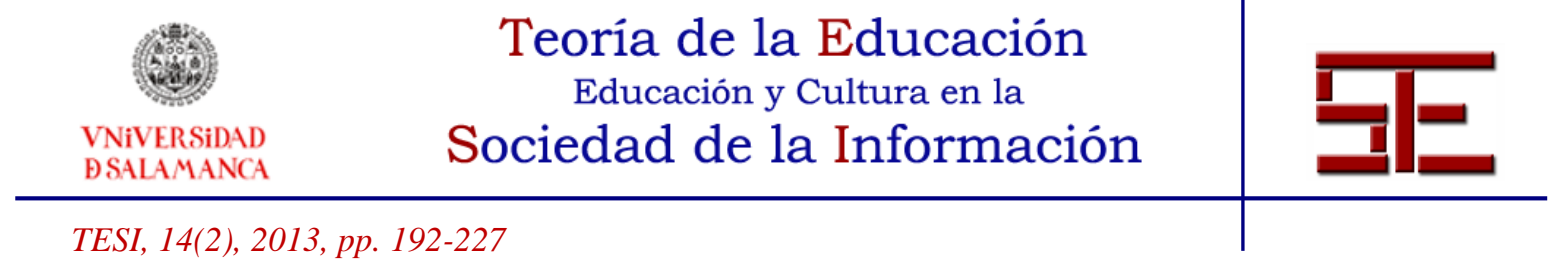

Esto nos hace pensar que el diseño de la página ha sido capaz de recrear una atmósfera capaz de trasladarnos a la escuela de otra época. La investigación en la que se sustenta el museo presencial y la página web ofrecen una museografía evocadora que facilita un viaje en el tiempo a la escuela del pasado, lo que justifica que todos los encuestados respondan afirmativamente a la consulta de si es posible investigar sobre la escuela del pasado a través de la página web. Vertiendo en la página partes de la investigación sobre las que se fundamenta el museo, se ha potenciado el descubrimiento, permitiendo al usuario crear sus propias hipótesis y conclusiones.

\section{- Interés por el audiovisual promocional del museo}

El 55,2\% no ha visionado el audiovisual promocional del museo ubicado en la página, mientras que sí lo hizo el 44,8\%. De los que lo han visto, el $82,8 \%$ considera que es apropiado incluir el audiovisual promocional en la página. El 10,3\% cree que no y el 6,9 no responde a esta pregunta.

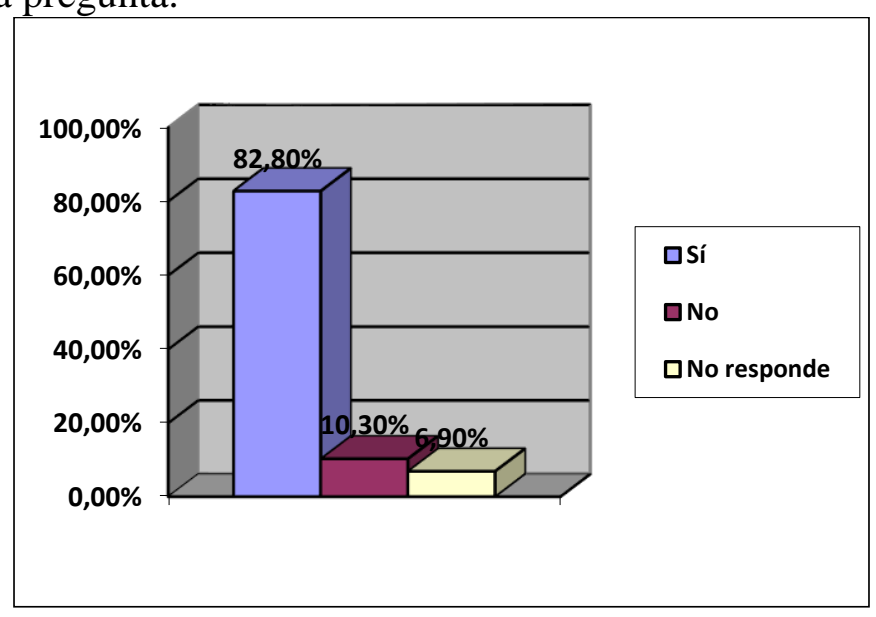

\section{Gráfico 5. Satisfacción con el audiovisual promocional del MERA.}

Este gráfico contiene uno de los datos más negativos que ofrece el análisis del cuestionario, puesto que debemos tener en cuenta que el público objeto de nuestro estudio tiene una media de edad de 23 años y por lo tanto es un sector de población acostumbrado al medio audiovisual. El audiovisual promocional recrea la vida en la escuela en formato de corto e incluye escenas de la escuela republicana y franquista, con golpes efectistas. El hecho de que solo un $44,8 \%$ de los encuestados se haya interesado por ver el audiovisual es paradójico y podemos pensar que se debe a una promoción inadecuada del mismo, que no le confiere la importancia que en realidad tiene.

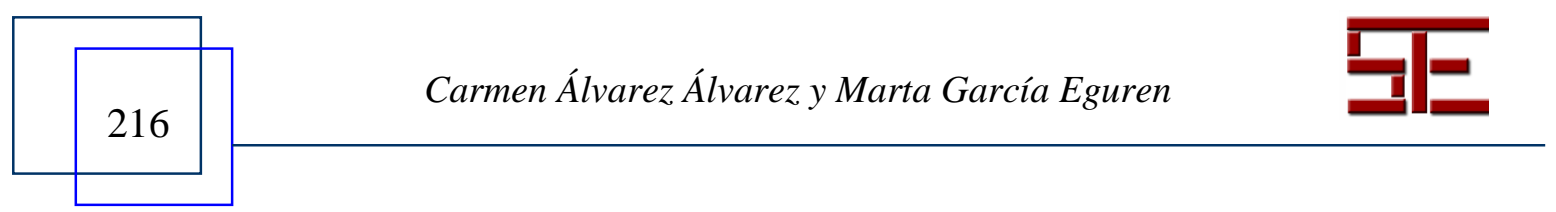




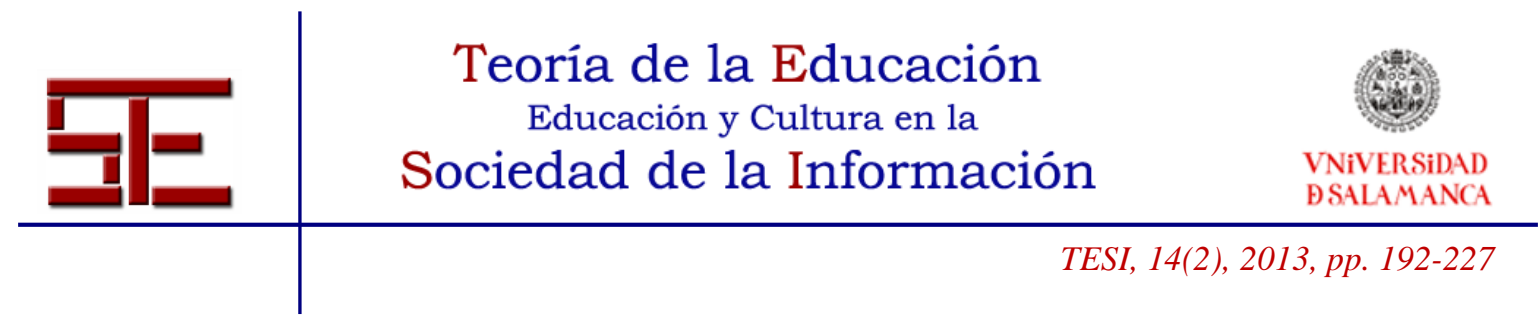

- La web permite comparar criterios pedagógicos

El $86,2 \%$ de los encuestados opina que a través de la consulta de la página se pueden comparar los diferentes criterios pedagógicos en la Historia de la Educación.

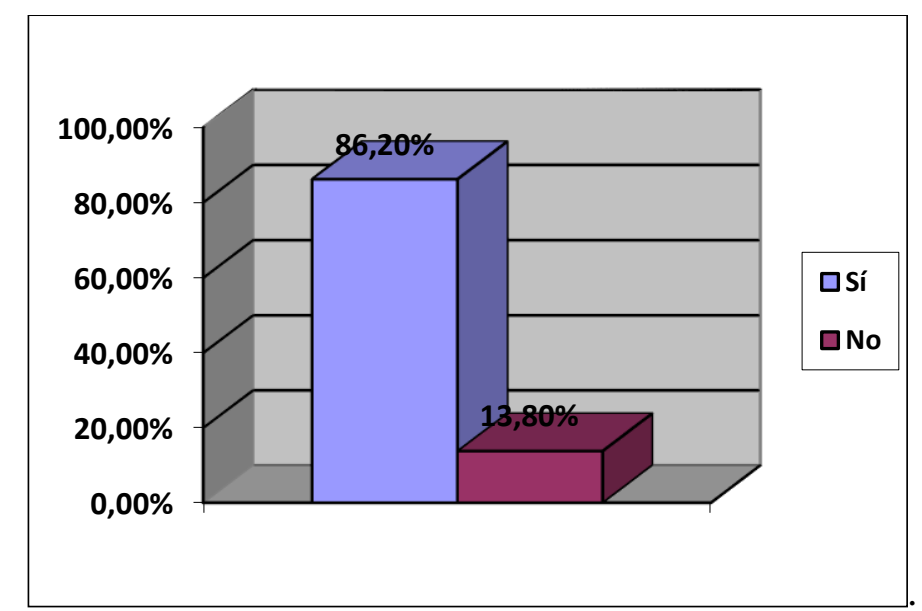

Gráfico 6. Capacidad de la página para comparar criterios pedagógicos.

Esta afirmación tiene mucho interés, ya que en la formación del Magisterio el alumnado no recibe formación específica en Historia de la Educación a lo largo de su formación inicial (en todo el plan de estudios solamente se estudia Didáctica de la Historia en la asignatura Didáctica de las Ciencias Sociales). El hecho de que el 86\% de los encuestados considere que la web es útil en este sentido es algo positivo.

\section{- Simular una clase retrospectiva}

El 86,2\% de los encuestados piensa que es posible, dada la museografía, simular una clase retrospectiva en las salas que componen el museo.

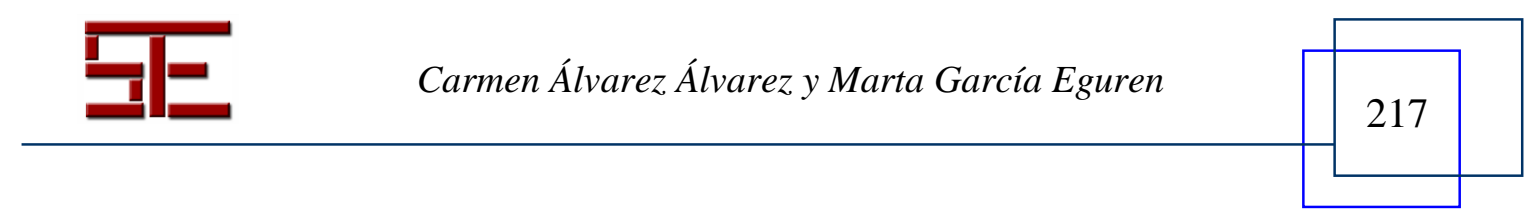



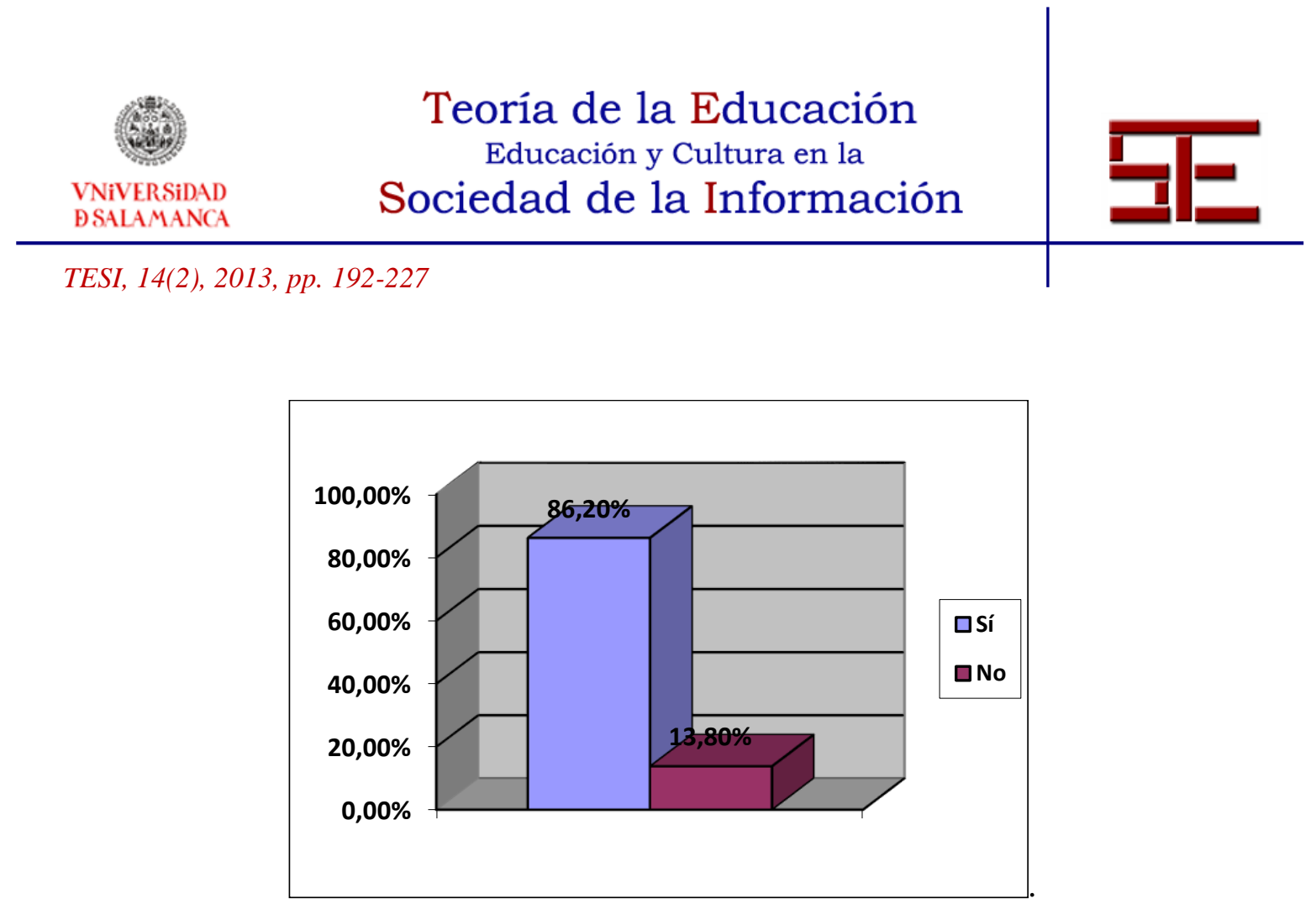

Gráfico 7. Capacidad de simular una clase retrospectiva.

La mayoría de los encuestados pueden imaginar una clase en la escuela del pasado en el espacio del museo, puesto que las salas se convierten en una escuela de otra época, en la que es posible, merced al mobiliario y a los materiales, trasladarse a la etapa republicana, a la escuela de final de los años 30, a la década de los 40, 50, o a finales de los años 60, en un aula compuesta por niños y niñas o en un espacio dedicado exclusivamente al sexo femenino.

\section{- Acudir al museo tras visitar la página}

El 96,6\% de los encuestados manifiestan su intención de acudir al museo después de visitar la página web.
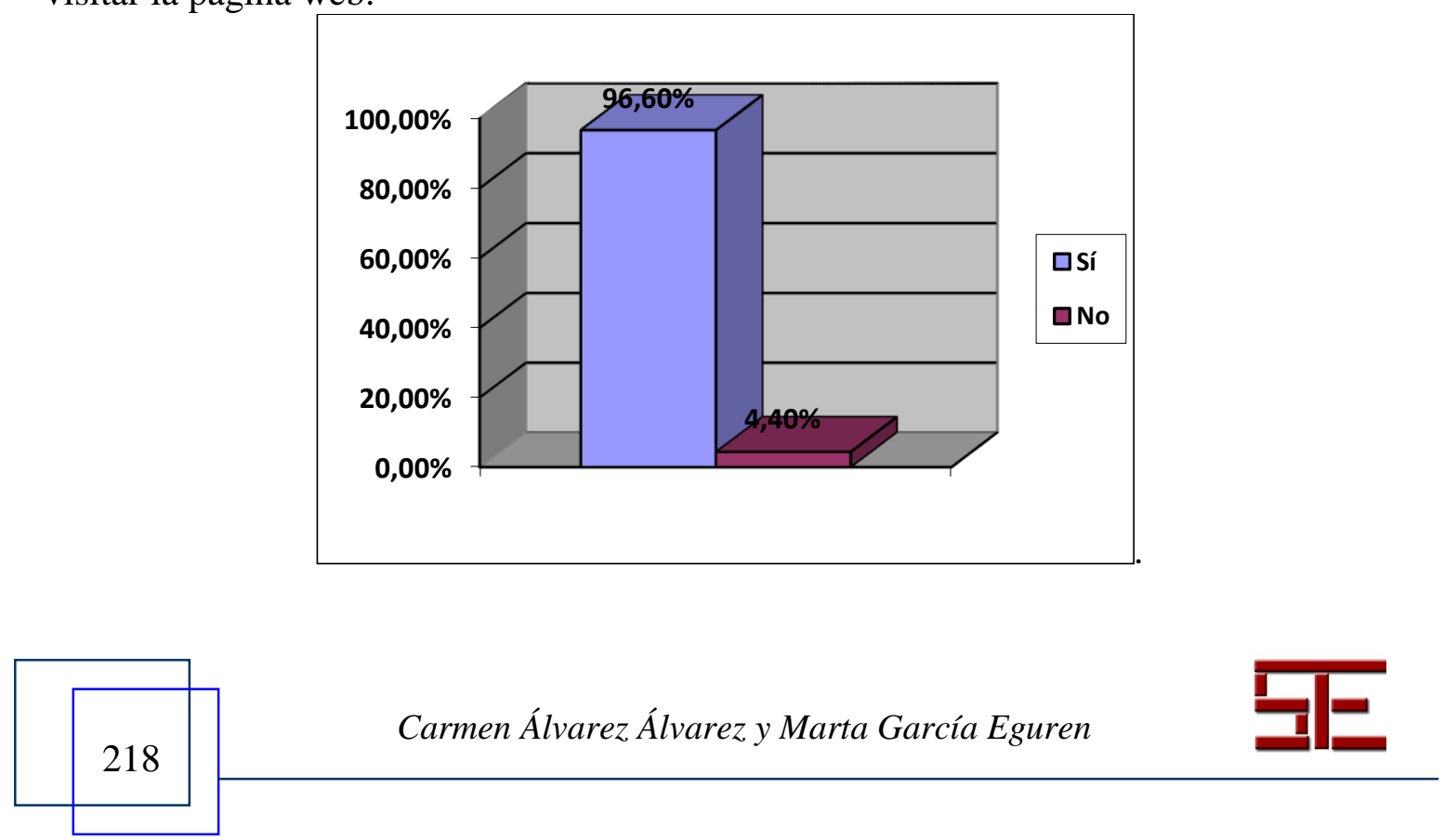


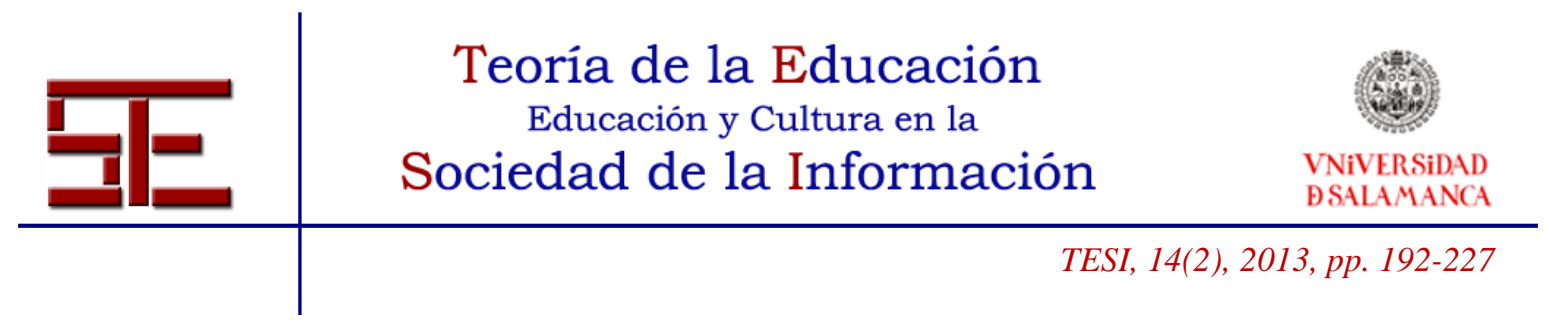

Gráfico 8. Intención de acudir a visitar el MERA tras la visita a la página web.

Solo un 4,4\% del alumnado no logra interesarse por conocer el museo presencial una vez efectuada la navegación por la página web. En este sentido echamos de menos no haber incluido en el cuestionario preguntas abiertas para tratar de comprender la motivación que les lleva a dar esta respuesta negativa. Sin embargo, la mayoría del alumnado desea visitar el museo después de conocerlo de forma virtual, lo que sin duda alguna interpretamos como un signo positivo de motivación generado por la web ("efecto llamada").

\section{- Post visita}

El 75,9\% cree que encontrará información útil en la página, para consultar con posterioridad a la visita al museo. El $20 \%$ contesta negativamente y el $4,1 \%$ no responde.

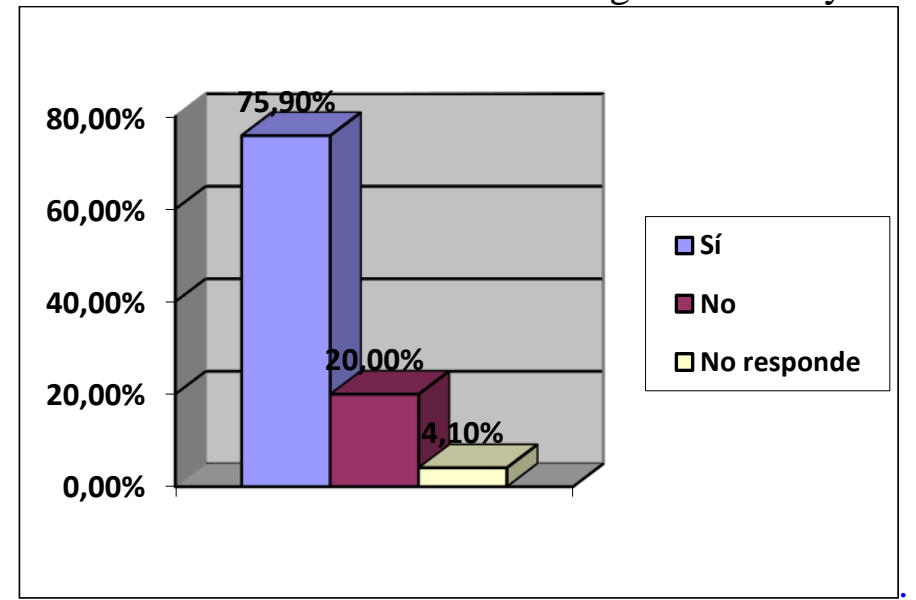

Gráfico 9. Interés de la página tras la visita presencial.

Toda web debe contener información para ser consultada antes de la visita, durante y después de ésta. La información antes de acudir al museo contribuye a crear determinadas expectativas, una vez que se conocen los contenidos que el discurso museológicomuseográfico puede aportar. La información post-visita es fundamental para profundizar en los conocimientos adquiridos durante la visita y cobran especial interés en un colectivo como el alumnado de Magisterio.

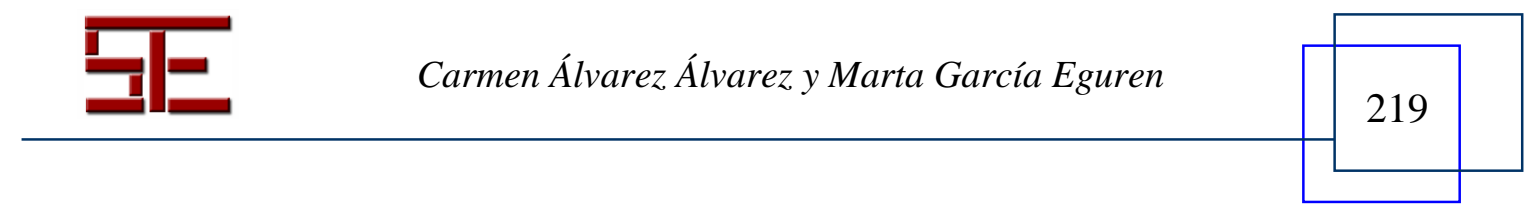




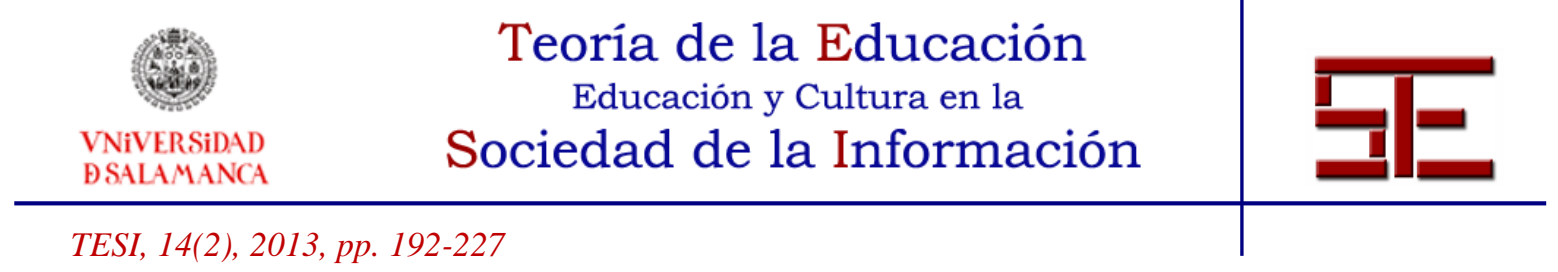

\section{CONCLUSIONES}

A tenor de los datos obtenidos podemos concluir que el diseño de la página resulta atractivo y sugerente para la mayoría de los encuestados. Más del $80 \%$ consideran que su estética conecta con el pasado, aspecto en conexión buscado como uno de los objetivos del diseño de la web, que hace que se mimetice el museo presencial y el virtual, con la gama bicromática de amarillos y tonos sepia, que evoca el tono de las fotografías antiguas y el papel envejecido, dándose un halo evocador que se potencia por la presencia de materiales que permiten una equiparación con el museo presencial.

La totalidad de los encuestados considera que, a través de la navegación por la página, se puede indagar e investigar sobre la escuela del pasado y también se pueden extraer ideas de cómo era la escuela en otras etapas. Para lograr este fin se incluye en la página una introducción al museo desglosada en: objetivos, Historia de la Escuela (1908-1970) historia del museo (2001-2007) y trayectoria y personajes clave, tanto para la fundación de la escuela, como para el posterior nacimiento del museo. Así mismo se han incluido documentos y testimonios obtenidos por medio de entrevistas e historias ficticias basadas en hechos reales. Los personajes protagonistas del material didáctico Guía para familias están reflejados en la página e inspirados en personajes reales, tanto en su historia personal, como en el parecido físico.

Esta idea viene apoyada en la página con la inclusión del audiovisual promocional que recrea la convivencia en el aula y conecta con la vida doméstica del maestro. El 55,2\% de los encuestados no ha visionado el audiovisual promocional del museo ubicado en la página, mientras que sí lo hicieron el $44,8 \%$. Este punto invita a la reflexión puesto que el $82,8 \%$ considera que es apropiado incluir el audiovisual promocional en la página, el $10,3 \%$ cree que no y el 6,9 no responden a esta pregunta. Una gran mayoría responde que es acertada la inclusión del audiovisual promocional en la página, en cambio es visionado por una cifra menor al 50\%. La respuesta quizá esté demandando una revisión, que conduzca a efectuar un cambio en la promoción del audiovisual en la propia página, con una carátula más atrevida que invite al visionado.

El 86,2\% de los encuestados opina que a través de la consulta de la página se pueden comparar los diferentes criterios pedagógicos y metodológicos en la Historia de la Educación, permitiendo la comparación entre el pasado y el presente. El visitante virtual tiene la posibilidad de iniciar un recorrido que discurre en paralelo a la estructura que encontramos en el museo presencial, donde se muestran mediante imágenes y textos dinámicos los espacios más relevantes que recrea la musealización evocadora del MERA.

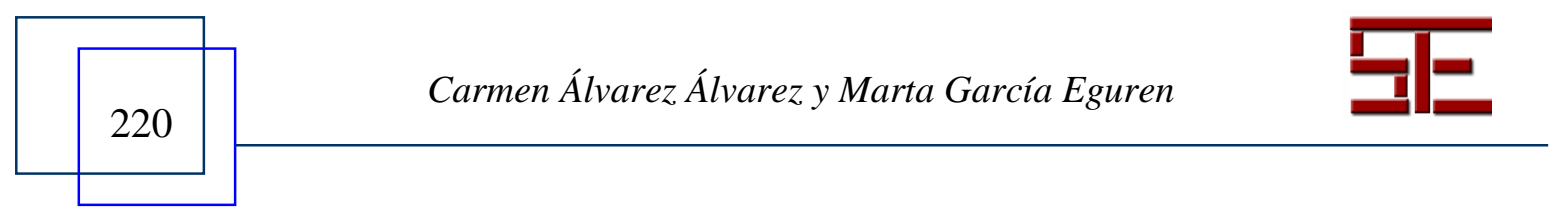




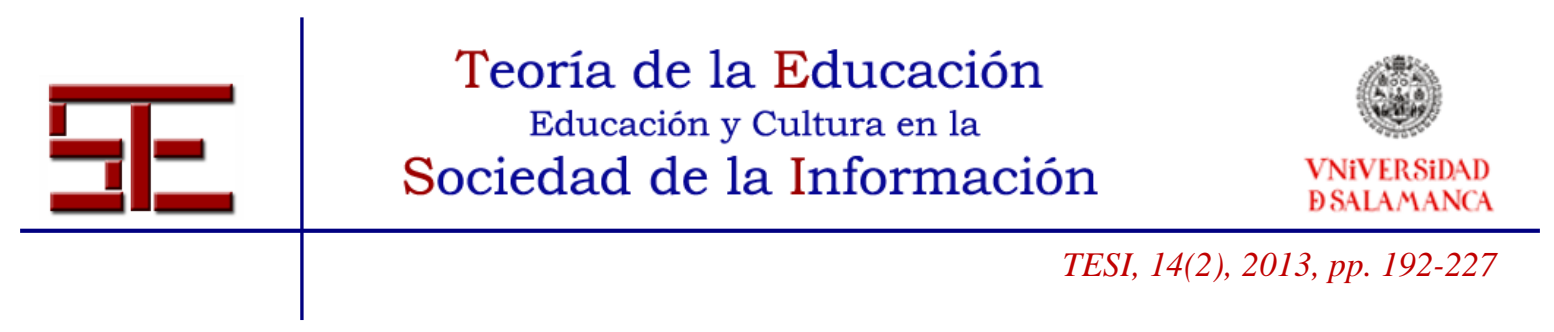

Ello conduce a que el $86,2 \%$ de los encuestados responda de manera afirmativa a la posibilidad de simular una clase real retrospectiva en las salas que componen el museo real. Entendemos, por medio de este resultado, que los encuestados valoran positivamente el poder de la museografía, y consideramos que implícitamente se está valorando el poder didáctico que alberga un espacio que resulta diferente al habitual, percatándose que tras él existe un modelo didáctico que persigue una enseñanza del contenido patrimonial que ofrece innovadoras metodologías, dentro del ámbito de las ciencias sociales.

El 96,6\% de los encuestados manifiestan su intención de acudir al museo después de visitar la página. Interpretamos a través de este resultado que la página web cumple su función de difusión, dando a conocer el museo como recurso. Además, esta respuesta va unida a otras que competen a los contenidos del museo y ratifican uno de los objetivos del proyecto museológico, que era hacer del museo un espacio para recrear en mundo de la escuela rural en Asturias y dotarlo de diferentes niveles de lectura. En este sentido el $75,9 \%$ cree que encontrará información útil en la página para consultar con posterioridad a la visita al museo. Para ello, igual que ocurre en las salas del museo se ha replicado la sección: para saber más, que ampliará los conocimientos del usuario, de forma más detallada.

Las conclusiones que podemos extraer del resultado obtenido del análisis ${ }^{6}$ del cuestionario realizado a los estudiantes de Magisterio, para conocer las expectativas que se generan en ellos sobre el MERA, después de la navegación por su página web, confirman la hipótesis de partida, donde se trataba de comprobar si cuatro años después de abrir la página web del museo en Internet mantenía su vigencia y potencial para atraer a este sector de público.

Después de observar los resultados obtenidos, fruto del análisis de los cuestionarios respondidos por estudiantes de tercer curso de Magisterio, hemos podido comprobar que existen concordancias con los resultados del estudio previo efectuado por Calaf (2009), donde se exploraba la satisfacción de las expectativas formativas que ofrece la visita al Museo de la Escuela Rural de Asturias como un espacio para la formación en

\footnotetext{
${ }^{6}$ Se realizó también un análisis bidimensional comparativo de los datos, mediante tablas de contingencia. Aunque algunos datos, mediante estudio de chi cuadrado, resultaron estadísticamente significativos, con una significación asintónica bilateral inferior a 0,05 , hemos considerado que incluir dichos resultados no aporta información relevante, ya que la muestra es homogénea y la $\mathrm{N}$ no es numerosa, lo cual sesga el resultado.
}

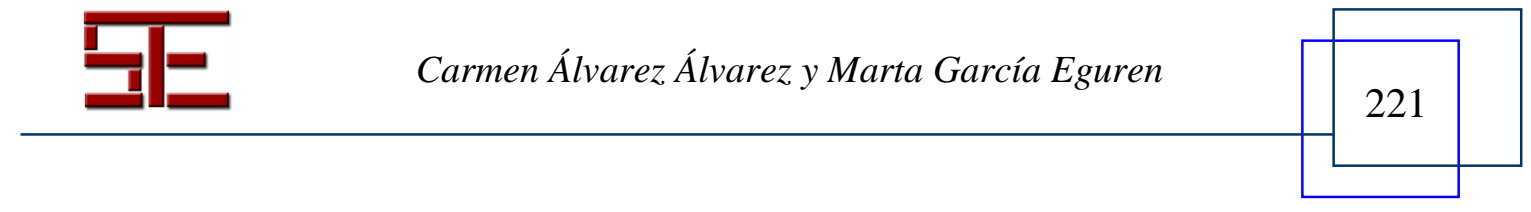




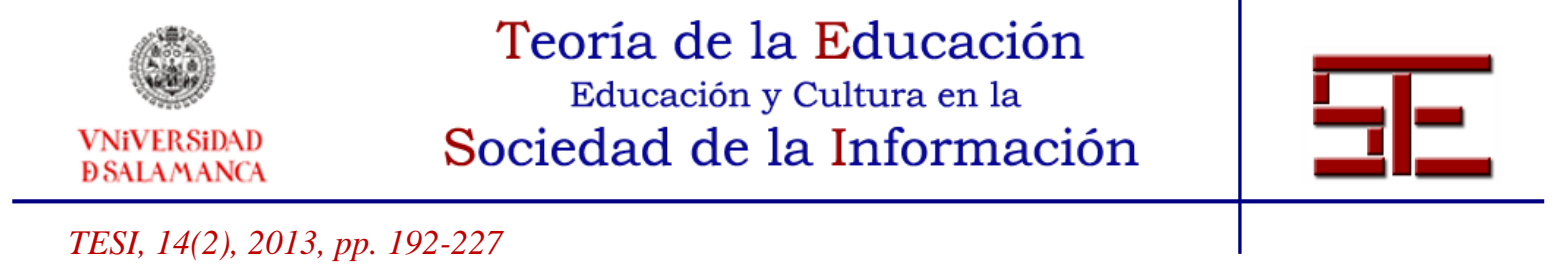

competencias para una práctica profesionalizada. En este sentido encontramos similitudes entre las expectativas que genera la visita a la página web en nuestro estudio y los resultados obtenidos por Calaf (2009) en los cuestionarios efectuados después de la visita de los estudiantes al Museo de la Escuela Rural.

En nuestra investigación, en las respuestas del cuestionario encontramos que la satisfacción de las personas entrevistadas alcanza una valoración elevada. Los estudiantes reconocen la gran carga didáctica que poseen las imágenes y materiales del museo, así como las posibilidades que proporciona, para el aprendizaje, el hecho de trabajar directamente con dichos recursos (González Monfort, 2006) que llevan a identificar al MERA, como un espacio idóneo para valorar el patrimonio etnográfico y entenderlo como instrumento para el aprendizaje de la historia sobre conceptos clave como son los de cambio, continuidad, empatía, tiempo y causalidad. Atendiendo al resultado del cuestionario sobre las expectativas que suscita la página web del museo entre los estudiantes, podemos considerar que el MERA es un espacio idóneo y complementario para la formación del profesorado y que la página web es vista por el alumnado como una herramienta para el aprendizaje.

No obstante, estos resultados positivos no deben llevarnos a pensar que ya está todo logrado. La página web ha de estar constantemente actualizada ¿Qué aspectos necesita mejorar? Algunos resultados negativos pueden indicarnos las acciones más inmediatas. Asimismo, los resultados positivos deben llevar a las personas implicadas en la implementación de la web a formular nuevos retos como la creación de un Museo Pedagógico Virtual, como planteábamos al principio, o la apertura de la página a otros sistemas de difusión, como pueden ser las redes sociales, actualmente en boga, sobre todo Facebook y Twitter. Lo ideal sería que un museo pudiera contar con un equipo de personas multidisciplinar, amplio y formado, que pudiera afrontar todos los pequeños y grandes retos que la difusión del patrimonio escolar virtual puede plantear. Una página web no debe ser un repositorio de ideas, imágenes y enlaces que se hace de una vez y para siempre, sino un ente vivo que se renueva y crece con recursos y se retroalimenta con su público, dando satisfacción a las necesidades reales del entorno en el que se inserta, permitiendo el uso y disfrute de diferentes tipos de usuarios.

El uso de redes sociales, por ejemplo, puede contribuir a difundir el museo pedagógico y facilitar su diseminación por una de las formas de marketing más fiables: el llamado fenómeno boca-oreja, un sistema que toda institución desea que se produzca.

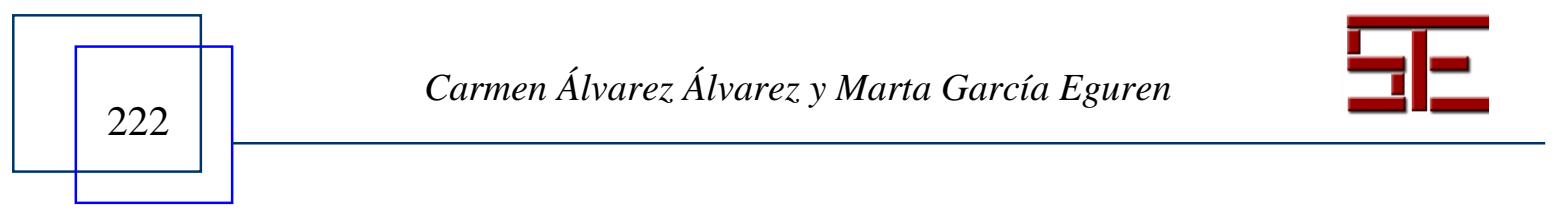




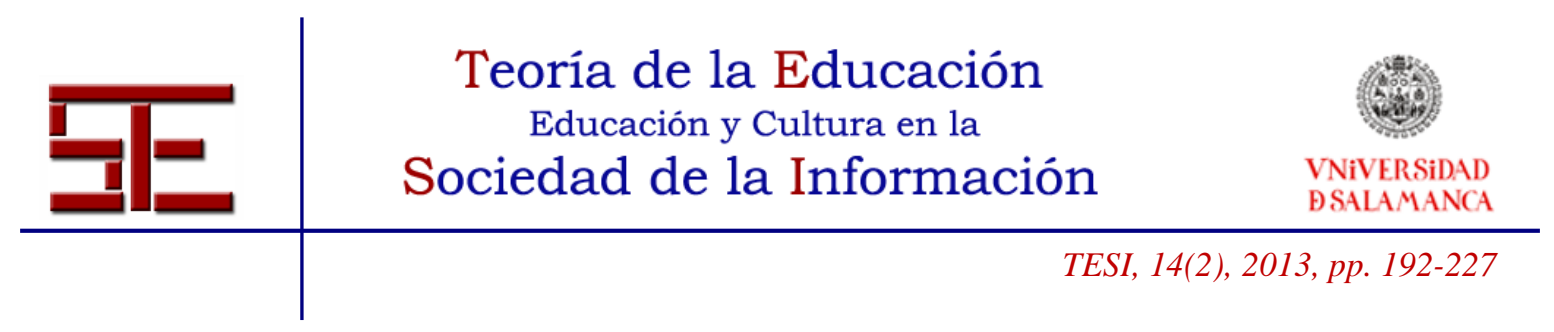

El uso de blogs es un caudal inagotable de información porque en ese espacio pueden convivir diferentes tipos de público, puesto que podemos calificar al Museo de la Escuela Rural de Asturias como un espacio vinculado a la evocación de la propia experiencia escolar-afectiva del pasado, que produce sentimientos en el visitante, y que le impulsan a desear dejar constancia de ellos por escrito, al igual que lo hacen en el museo real, pero con la ventaja de hacerlo en la intimidad y sin límite de tiempo o espacio. Estos testimonios tienen un gran valor tanto para el museo como para su público. Los blogs también son el caldo de cultivo ideal para que confluyan en ellos los profesionales, los cuales pueden unir sus recuerdos a sus conocimientos, enriqueciéndonos a todos con el producto que surge entre la unión del corazón y la razón.

La página web es el receptáculo ideal para insertar otro tipo de herramientas que abarcan desde unas coordenadas para encontrar lugares recónditos hasta la posibilidad de anular barreras. Por medio de la tecnología, simplemente incluyendo un sencillo código QR, somos capaces de construir una guía didáctica interactiva, adecuada a diferentes públicos, ya sean adultos, público infantil o público con necesidades especiales. Este último colectivo puede experimentar grandes novedades que facilitan y acercan tanto el disfrute como el aprendizaje, logrando el nivel de comunicación interactiva, que supone la explotación extensiva e intensiva del ámbito hipermedia.

Pero las páginas web también es necesario, como plantean en su investigación Payá y Álvarez (2012), hacerlas visibles en plataformas de recursos diferentes. En esta línea un grupo de profesores de la Universidad de Valencia movidos por la necesidad de contar con un espacio de aprendizaje para facilitar la didáctica del patrimonio educativo $\mathrm{y}$, particularmente, tras la participación en otros proyectos de I+D+I, diseñaron y elaboraron un espacio virtual de aprendizaje para el estudio del patrimonio educativo, creando la plataforma www.patrimonioeducativo.es concebida como un espacio virtual organizado con enlaces a varios recursos recomendados, temas, archivos, tareas, actividades de aprendizaje, vínculos, etc., utilizando los foros de participación y las redes sociales como elementos de comunicación y conocimiento.

Pero, en todo caso, no debemos olvidar que la página web de un Museo Pedagógico no es sino una fórmula más para acercar el patrimonio escolar en sus diversas formas y manifestaciones a los diferentes usuarios, por lo que, al igual que el museo presencial, debe contener informaciones útiles, actuales y documentadas científicamente en Historia de la Educación y debe renovarse a la par que lo hace el museo real, o incluso adelantarse a éste, ya que la web de un museo puede permitir otras formas innovadoras de

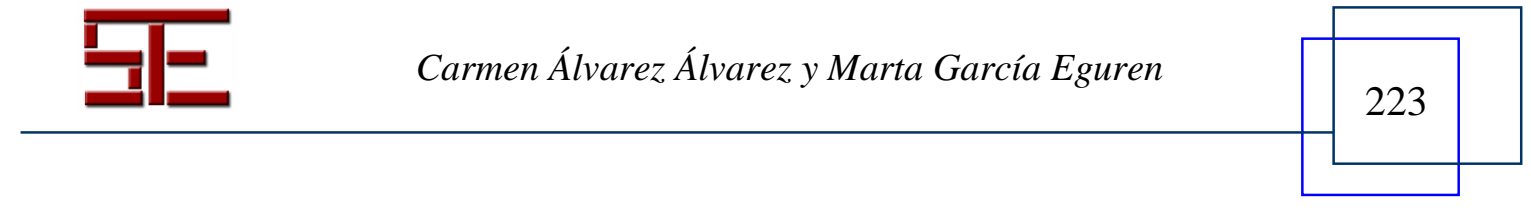




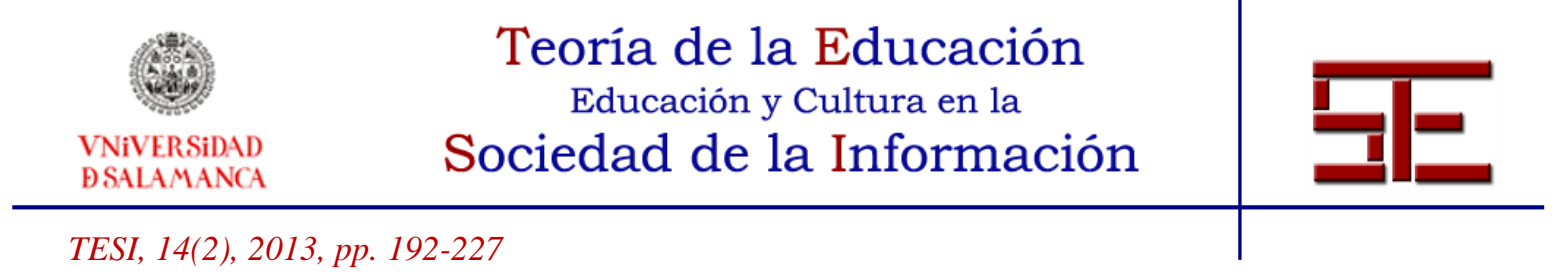

experimentación con el patrimonio. Es necesario desterrar la idea dominante de que la página web de un Museo Pedagógico es un tablón de anuncios. La página web de un Museo Pedagógico debe ser un recurso educativo y debe cumplir una función innovadora, aportando nuevas maneras de enseñar y nuevas formas de aprender.

\section{REFERENCIAS BIBLIOGRÁFICAS}

Álvarez, C. \& García Eguren, M. (2011). Museos pedagógicos: ¿Museos didácticos? Didáctica de las Ciencias Experimentales y Sociales, 25, 103-116.

Álvarez, C. \& San Fabián, J. L. (2012). La elección del estudio de caso en la investigación cualitativa. Gazeta de Antropología, 28/1. Extraído el 7 de mayo de 2013, de http://www.ugr.es/ pwlac/G28_14Carmen_Alvarez-JoseLuis_SanFabian.pdf.

Álvarez, P. (2010). El conocimiento y difusión del patrimonio histórico-educativo de Andalucía en internet a través del Museo pedagógico andaluz. Cabás, 3. Extraído el 10 de enero de 2013 de http://revista.muesca.es/index.php/remository?func=fileinfo\&id=61

- . (2012). El museo de educación como recurso didáctico mediante las tecnologías de la información y la comunicación (TIC). Revista de Ciencias de la Educación, 231-232, 361-374.

Asensio, M. \& Pol, E. (2002). Nuevos escenarios en educación. Aprendizaje informal sobre el patrimonio, los museos y la ciudad. Buenos Aires: Aique.

Bassey, M. (2000). Case study research in educational settings. Buckinghan: Open University Press.

Calaf, R. (2009). Didáctica del Patrimonio. Epistemología, metodología y estudio de casos. Gijón: Trea.

Calaf, R. \& Fontal, O. (Coords.) (2006). Miradas al patrimonio. Gijón: Trea.

Cebreiro, B. \& Fernández, M. C. (2004). Estudio de casos. En F. Salvador, J. Rodríguez \& A. Bolívar, Diccionario Enciclopédico de Didáctica. Málaga: Aljibe.

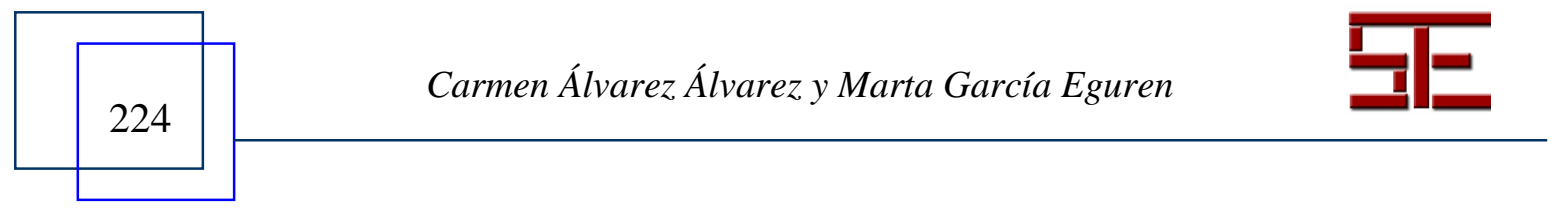




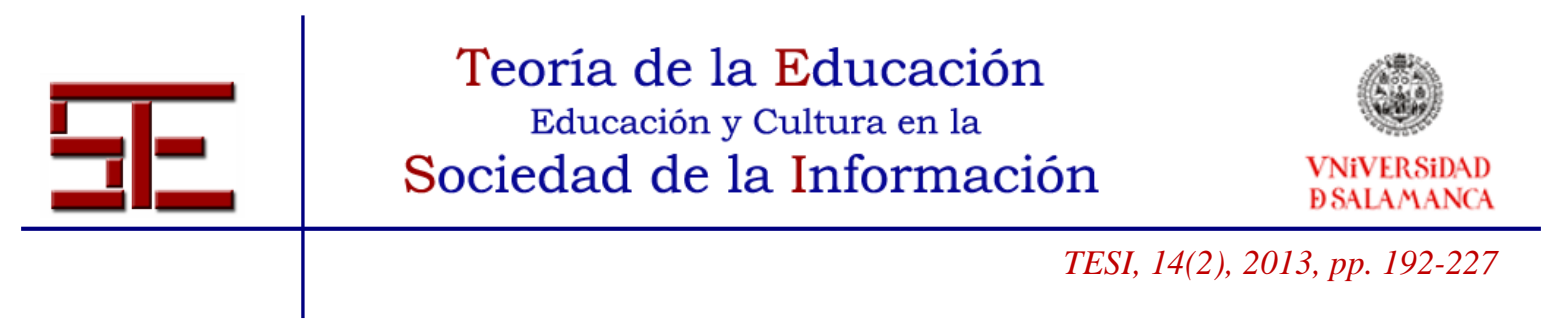

Chavarría, X., Hampshire, S. \& Martínez, F. (2004). Una aproximación a los estudios de caso desde la práctica. Revista de Investigación Educativa, 22, 443-458.

Coller, X. (2005). Estudio de casos. Madrid: Centro de Investigaciones Sociológicas.

Cuenca, J.M. (2006). La mirada de los maestros, profesores y gestores del patrimonio. Investigación sobre las concepciones acerca del patrimonio y su didáctica. En R. Calaf \& O. Fontal (Coords.), Miradas al Patrimonio (pp. 51-71). Gijón: Trea.

Escolano, A. (2007). El sujeto en el nuevo paradigma historiográfico de la cultura de la escuela. En J. Gómez, G. Espigado \& M. Beas (Eds.), La Escuela y sus escenarios (pp. 133-150). Sanlúcar de Barrameda: Ayuntamiento de El Puerto de Santa MaríaSerie Encuentro de Primavera.

García Eguren, M. (2006). Recuperar el patrimonio etnográfico e implementar las acciones para la construcción de un museo. En R. Calaf \& O. Fontal, (Coords.). Miradas al patrimonio (pp. 293-310). Gijón: Trea.

- (2010). "Relación museo territorio e implementación didáctica: Museo de la Escuela Rural de Asturias". Tesis doctoral. Universidad de Oviedo, Departamento de Ciencias de la Educación. Extraído el 12 de mayo de 2013, de http://www.tdx.cat/handle/10803/84148

González Monfort, N. (2006). ¿Puede el Patrimonio Cultural ser un recurso educativo relevante en la enseñanza y el aprendizaje de la Historia en la Educación Primaria? Sugerencia para la formación del profesorado. En A. E. Gómez \& M. P. Núñez, Formar para Investigar, Investigar para Formar en Didáctica de las Ciencias Sociales (pp.75-88). Málaga: Asociación Universitaria del Profesorado de Didáctica de las Ciencias Sociales.

Grandon, T. (2011). Book Informing with the Case Method. London: Informing Science Press.

Huerta, R. (2011). Maestros, museos y artes visuales. Construyendo un imaginario educativo. Arte,Individuo y Sociedad, 23 (1), 55-73.

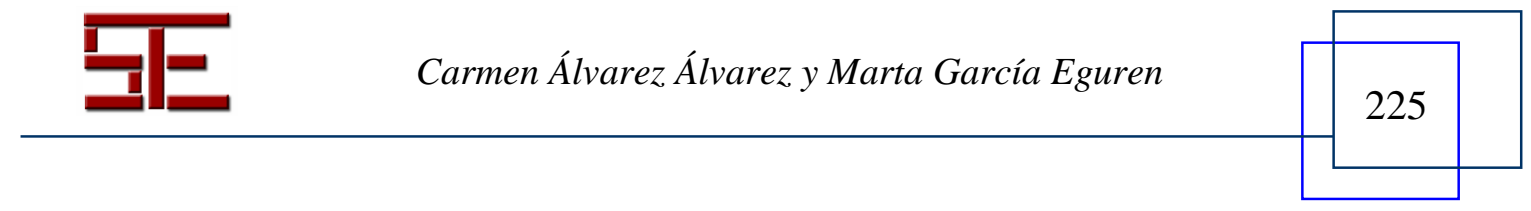




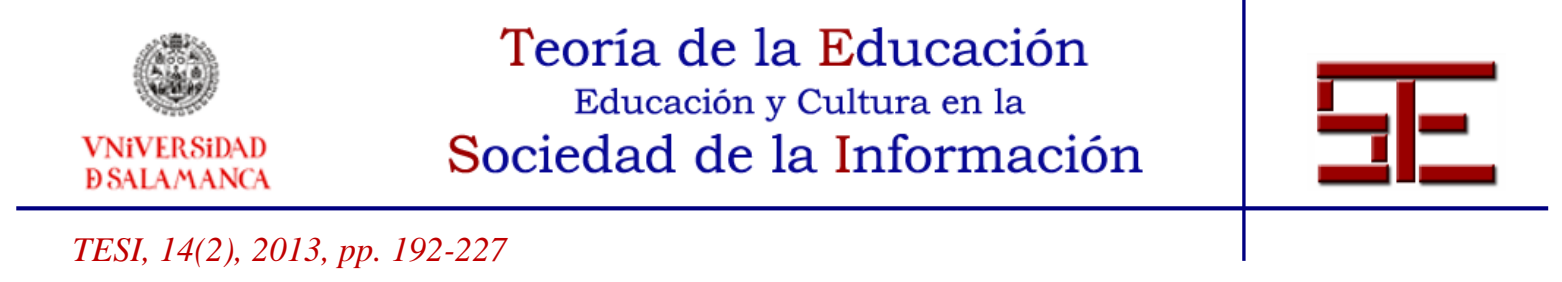

Landry, A. \& Meunier, A. (Coord). (2008). La recherche en Éducation Muséale: Actions et perspectives. Québec: Multimomdes.

López, J., Elola, M. \& García, M. (2011). La complicidad del museo y el territorio: la Red de Museos Etnográficos de Asturias. Her\&Mus: Heritage \& Museography, 32 , 31-37.

Loran, M. (2005). L'ús dels webs per a afavorir l'accési l'increment de públic als museus:experiències dels museus nacionals britànics. Digithum, 7. Extraído el 12 de julio de 2012, de http://www.uoc.edu/digithum/7/dt/cat/loran.pdf

Martínez, P. C. (2006). El método de estudio de caso. Estrategia metodológica de la investigación científica. Pensamiento y gestión, 20, 165-193.

Martínez, R. A. (2007). La investigación en la práctica educativa: Guía metodológica de investigación para el diagnóstico y evaluación en los centros docentes. Oviedo: Secretaría General Técnica del MEC/CIDE.

Mateos, S. (2008). La comunicación global del patrimonio cultural. Gijón: Trea.

- (2012). Manual de comunicación para museos y atractivos patrimoniales. Gijón: Trea.

Payá, A. \& Álvarez, P. (2012). Pensar la educación desde las TIC y la recuperación del patrimonio educativo. En O. Fontal (Coord.), Mirando a Europa: estado de la cuestión y perspectivas de futuro (pp. 546-554). Madrid: Ministerio de Educación, Cultura y Deporte.

Rivero, M. P. (2009). Museos y didáctica on-line: cinco ejemplos de buenas prácticas. Her \& Mus: Revista de Museología, 110, 109-114.

Santacana, J. \& Llonch, N. (2009). Museo local. La cenicienta de la cultura. Gijón: Trea.

Santacana, J. \& Martín Pinol, C. (2010). Museografía interactiva. Gijón: Trea.

Soren, B. J. (2005). Best practices in creating quality online experiences for museum users.Museum Management and Curatorship, 20, 2, 131-148.

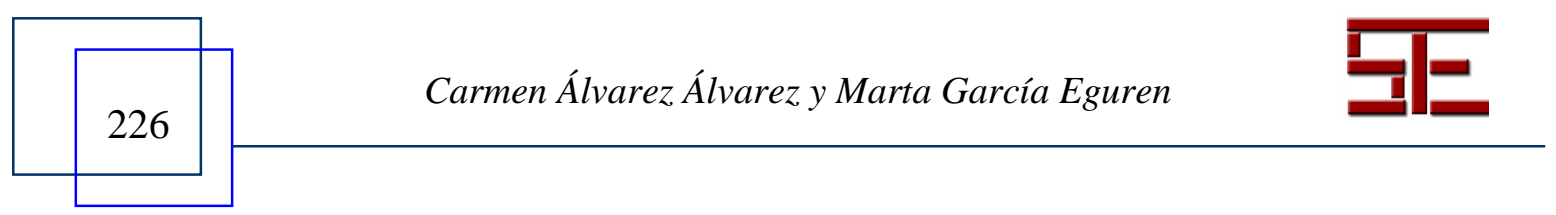




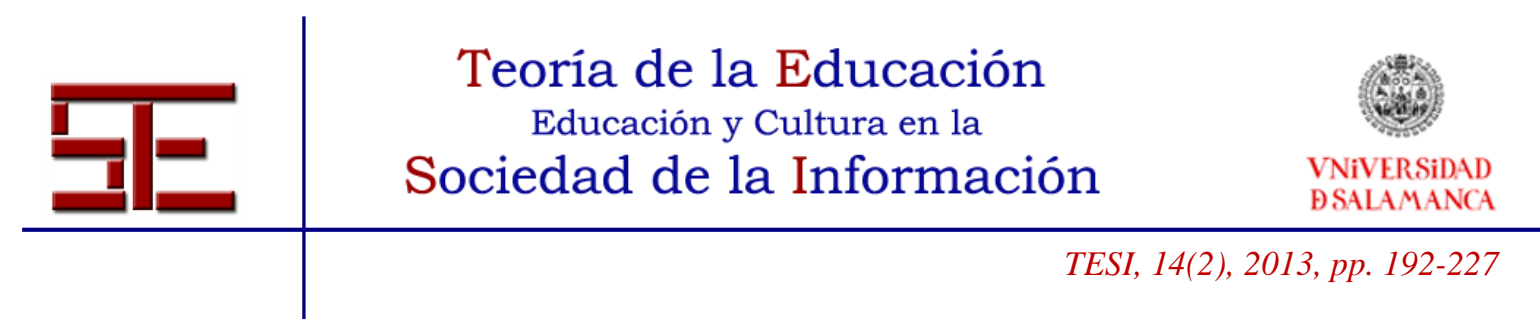

Stake, R. E. (2005). Investigación con estudio de casos. Madrid: Morata.

Vicente, E., Camarero, C. \& Garrido, M. J. (2012). Insights into innovation in European Museums. Public Management Review, 14 (5), 649-679.

Yacuzzi, E. (2005). El estudio de caso como metodología de investigación: teoría, mecanismos causales, validación. Inomics, 1, 296-306.

Wagensberg, J. (2001). Principios fundamentales de la museología científica moderna. Revista BMM, 55, 22-24.

Para citar el presente artículo puede utilizar la siguiente referencia:

Álvarez Álvarez, C. y García Eguren, M. (2013). La utilidad de las TIC para la promoción de aprendizajes en un museo pedagógico en internet: diseño, desarrollo y evaluación. Revista Teoría de la Educación: Educación y Cultura en la Sociedad de la Información. 14(2), 192-227 [Fecha de consulta: dd/mm/aaa].

http://campus.usal.es/ revistas_trabajo/index.php/revistatesi/article/view/10220/10629

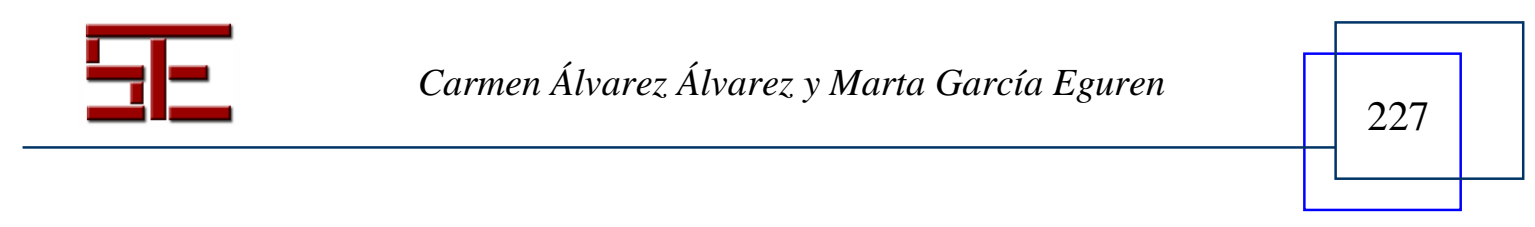

